\title{
TTP SR1-6-WT-31, Milestone XXX, Milestone C.1-2 Report: Functional Test of Pour Spout Insert and Knife Edge
}

by

D. F. Bickford

Westinghouse Savannah River Company

Savannah River Site

Aiken, South Carolina 29808

D. C. Iverson

R. Singer

H. Guerrero

M. E. Smith

E. K. Hansen

J. C. George

This paper was prepared in connection with work done under the above contract number with the U.S.

Department of Energy. By acceptance of this paper, the publisher and/or recipient acknowledges the U.S. Government's right to retain a nonexclusive, royalty-free license in and to any copyright covering this paper, along with the right to reproduce and to authorize others to reproduce all or part of the copyrighted paper. 
WSRC-TR-99-00232,

Revision 0

TIP SR1-6-WT-31

Milestone C.1-2 Report: Funtional Test of Pour Spout Insert and Knife-Edge(U)

D.F. Bickford, D.C. Iverson, H.N. Guerrero, M.E. Smith, E.K. Hansen , J.C. R.P. Singer

Approved by

E.W. Holtzscheiter, Research Manager

Defense Waste Processing Technology

Issue Date: July 9, 1999

Westinghouse Savannah River Co.

Savannah River Site

Aiken, SC 29808 
WSRC-TR-99-00232, Revision 0

\section{DISCLAIMER}

This report was prepared as an account of work sponsored by an agency of the United States Government. Neither the United States Government nor any agency thereof, nor any of their employees, makes any warranty, express or implied, or assumes any legal liability or responsibility for the accuracy, completeness, or usefulness of any information, apparatus, product, or process disclosed, or represents that its use would not infringe privately owned rights. Reference herein to any specific commercial product, process, or service by trade name, trademark, manufacturer, or otherwise does not necessarily constitute or imply its endorsement, recommendation, or favoring by the United States Government or any agency thereof. The views and opinions of authors expressed herein do not necessarily state or reflect those of the United States Government or any agency thereof.

This report has been reproduced directly from the best available copy.

Available to DOE and DOE contractors from the Office of Scientific and Technical Information, P.O. Box 62, Oak Ridge, TN 37831; prices available from (615) 576-8401.

Available to the public from the National Technical Information Service, U.S. Department of Commerce, 5285 Port Royal Road, Springfield, VA 22161. 


\section{DISCLAIMER}

Portions of this document may be illegible in electronic image products. Images are produced from the best available original document. 
WSRC-TR-99-00232, Revision 0

APPROVALS

Thereat C. Anis for DFB '

Dennis F. Beckford, Author
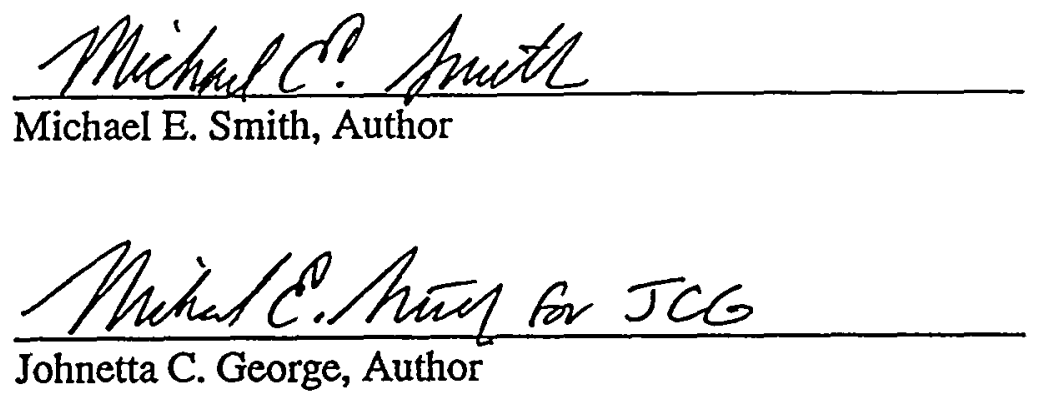

ENAbetzzchuter

E.W. Holtzscheiter, Technical Reviewer

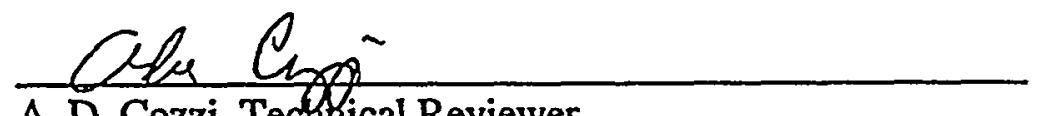

A. D. Cozzi, Technical Reviewer

En thetzechuten

E.W. Holtzscheiter, Level 3 Manager

Immobilization Technology Section $\frac{7-/ 5-99}{\text { Date }}$

$\frac{7-15-90}{\text { Date }}$

$\frac{7-15-99}{\text { Date }}$

$7-15-99$

Date

$\frac{7-15-99}{\text { Date }}$

$\frac{1-15-99}{\text { Date }}$

iii 
WSRC-TR-99-00232, Revision 0

\section{TTP SR1-6-WT-31}

Milestone C.1-2 Report: Functional Test of Pour Spout Insert and Knife-Edge(U)

D.F. Bickford, D.C. Iverson, H.N. Guerrero, M.E. Smith, E.K. Hansen, J.C. George, R.P. Singer

Issue Date: July 9, 1999

Westinghouse Savannah River Company

Savannah River Site

Alken, SC 29808

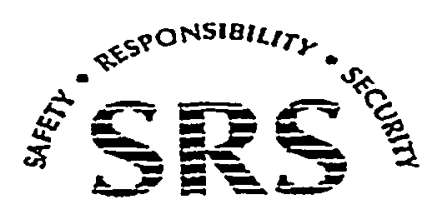

PREPARED FOR THE U.S. DEPARTMENT OF ENERGY UNDER CONTRACT NO. DE-AC09-96SR18500 
WSRC-TR-99-00232, Revision 0

EXECUTIVE SUMMARY 


\section{WSRC-TR-99-00232, Revision 0}

TABLE OF CONTENTS

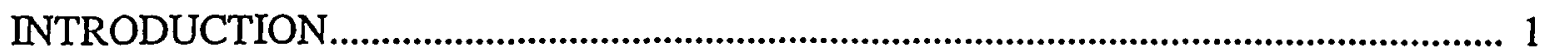

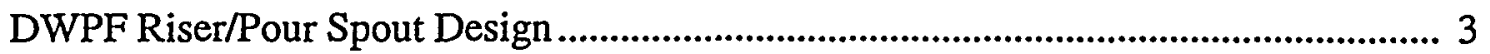

Full Scale DWPF Melter Pour spout Test Stand ....................................................... 3

TEST PROGRAM

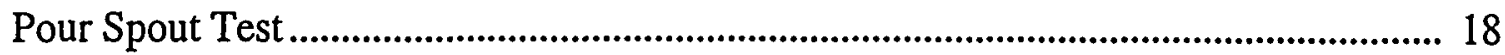

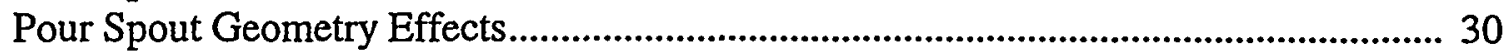

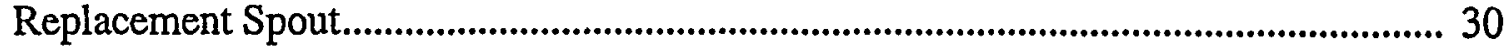

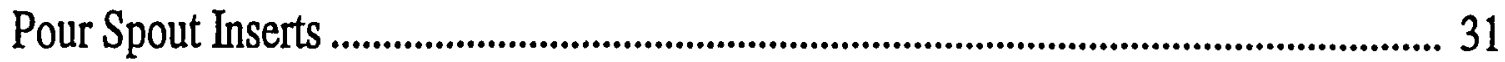

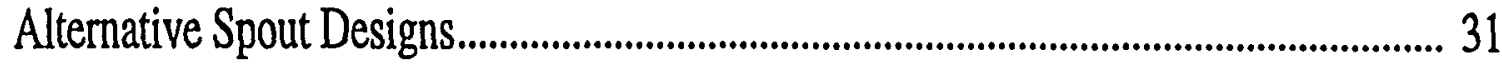

Wear \& Corrosion Tests............................................................................................. 31

Noble Metal Behavior and Effects...................................................................... 32

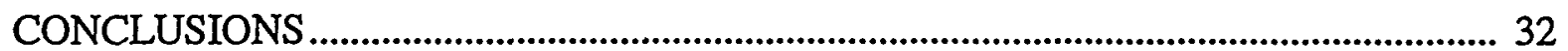

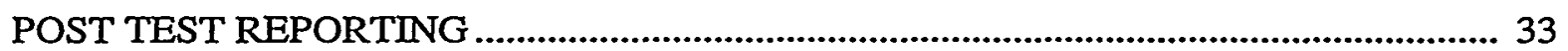

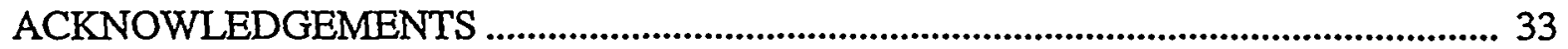

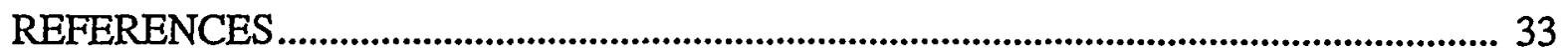




\section{WSRC-TR-99-00232, Revision 0}

\section{LIST OF ILLUSTRATIONS}

1 Schematic of DWPF glass melter and pour spout............................................................. 1

2a Schematic of melter pout spout showing removable insert................................................. 2

2b Inconel 690

Pour spout images

High resolution electronic camera image looking up at $1150^{\circ} \mathrm{C}$ upper knife edge................ 5

High resolution electronic camera image looking upspout at $1150^{\circ} \mathrm{C}$ showing near-asmachined condition of upper knife edge .............................................................................. 5

Insert installed in spout and at operating temperature........................................................... 5

Replaceable insert being installed in the test spout................................................................ 5

Insert mounted on the insertion tool, prior to installation .................................................... 6

Top view of the replaceable insert .................................................................................... 6

Side view of the replaceable insert.......................................................................................... 6

ISO Therm @ $1175^{\circ} \mathrm{C}$.............................................................................................................. 7

Thermal imaging viewing up the spout................................................................................... 8

Detail of the insert in the spout ............................................................................................ 8

Thermal image measuring temperature of glass falling through the spout............................. 8

High resolution electronic image looking into the spout ........................................................ 8

Two assembled electrical brushed used to replace the supplies buss bar and connectors .... 9

Inside of the new brush assembly showing the graphite electrical brush supported by a copper support................................................................................................................ 9

Graphs

Main pot heat up $6 / 21 / 99$................................................................................................. 10

Main pot 6/21/99 - Melter primary task temperatures at steady state without joule heat.... 10 Superheater checkout 5/17/99 -- In the Superheater TC! thermocouples are adjacent to heaters and TC2 thermocouples are adjacent to the tank .................................................. 12

Superheater 6/21/99 -- Superheater temperatures after installation of auxiliary heaters...... 13 


\section{WSRC-TR-99-00232, Revision 0}

Pour Spout Temperatures 6/22/99 -- Temperatures of the DWPF test Riser and Pour Spout set mimic the actual melter.

Pour Spout 5/17/99 -- Temperatures in the DWPF test Riser and Pour Spout, $1050^{\circ} \mathrm{C}$ setpoint.

Drain Side 6/21/99 -- Temperatures of the auxiliary heaters installed to improve glass heating in the Superheater (5 auxiliary heaters).

Drain Side 5/17/99 -- Temperatures of the auxiliary heaters installed to improve glass heating in the Superheater ( 3 auxiliary heaters)

3a-1 Glass Stream Behavior Inside an Insert During a 7.8 pound surge (5/19/99) 20

4a shows the position of the glass stream separation prior to the surge which is from the insert knife-edge

$4 b-4 c$ show the progress of the surge front from a 4 pound glass chunk dropped into the reservoir at the pour spout and insert, respectively.

5a shows the glass stream was separating from the insert knife-edge centerline 22

$5 \mathrm{~b}$ shows the surge front travelling down the insert.............................................................. 22

$5 c-5 d$ show the increasing height of the fluid inside the insert.............................................. 22

5e shows the large glass hump reaching the insert knife-edge and deflecting backwards.... 22

$5 \mathrm{~g}-5 \mathrm{~h}$ show termination of the large wick............................................................................ 22

5i shows the glass stream reaching a steady state and separating from the pour spout knife-edge centerline

6 a shows the position of the stream before the surge.

$6 \mathrm{~b}-6 \mathrm{e}$ show the increase in stream width and brightness during the surge and its movement backwards towards the riser.

6f shows the multiple steam resulting from the large wick hitting the insulation 23

7a-7i show the steady flow was $155 \mathrm{lbs} / \mathrm{hr}$ and the glass steam was separating from pour spout knife-edge

8a shows the initial position of the glass stream when the stream was separating from the insert knife-edge centerline. 


\section{WSRC-TR-99-00232, Revision 0}

$8 \mathrm{c}$ shows the front end of the glass stream separating from the insert knife-edge............... 25

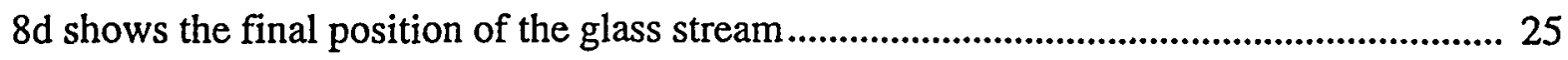

9a shows the steady state flow rate was $155 \mathrm{lbs} / \mathrm{hr}$ and the glass stream was separating from the insert knife-edge at about 30 degrees to the left of the centerline looking towards the riser. This figure also shows the 8 pound surge front approaching the spout knife-edge.

9b-9c show he flow built up inside the insert and there were several large wicks or wavering of the stream

$9 \mathrm{~d}$ show when the level in the pour spout had decreased (the stream separated from the pour spout knife-edge centerline

9f show there was a residual stream behind the main stream draining from the insert ........ 26

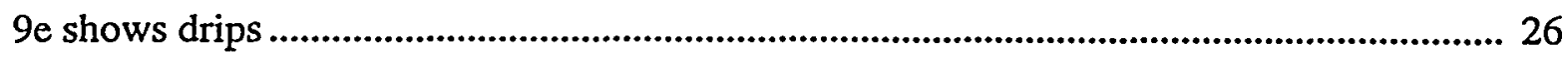

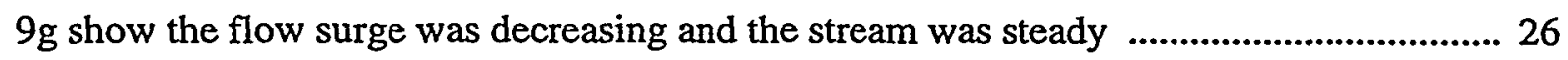

9i show the separating flow swung to the right (Figure 9h) and contacted the insert wall,

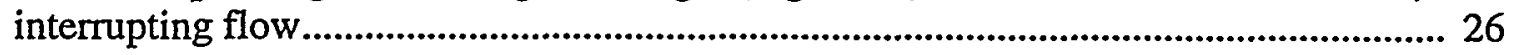

9j show the flow again built up inside the insert and separated from the insert knife-edge,

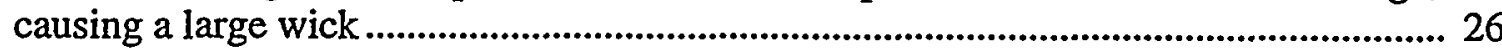

9k show the stream was again steady, separating from the insert knife-edge at about 30

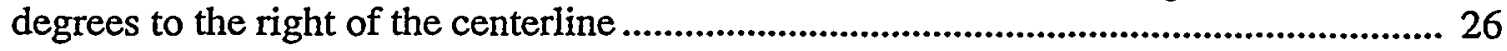

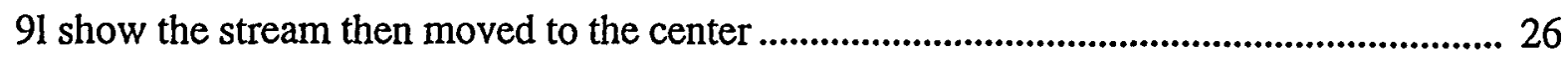

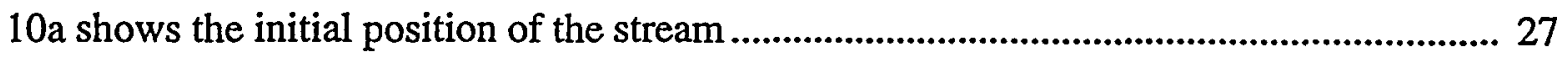

$10 \mathrm{~b}-10 \mathrm{f}$ show the movement of the stream back and forth from the center to the right....... 27

11a shows the initial flow separating from the insert knife-edge. The surge front due to a 4 pound drop test can be seen inside the pour.............................................................. 28

$11 \mathrm{~b}$, the stream deflects inside the insert and hits the insert wall. Glass then collects, and interrupts the flow out of the insert. Spreading of the glass downward is aided by gravity while capillary forces are limited in the lateral direction. This causes rounding of the stream and an increase in height, which might also be aided by surface tension. The leading edge of the surge front reaches the insert knife-edge and deflects backwards $9 \mathrm{e}$

11c shows the deflecting stream hitting the cold collected glass on the insulation opening 28 


\section{WSRC-TR-99-00232, Revision 0}

$11 \mathrm{~d}$, the increase in level in the pour spout results in continuous wicking9e shows drips ... 28

$11 \mathrm{e}$, the pour spout level has decreased to a medium level and a meniscus forms in the glass stream inside the insert........................................................................................... 28

$11 \mathrm{f}$ The glass then separates from the pour spout knife-edge and a repeated wicking occurs with a medium frequency, repeating the alternate glass separation from the pour spout and insert knife-edges

$11 \mathrm{~g}-11 \mathrm{i}$, the level in the pour spout has significantly decreased but surging still occurs inside the insert although with a longer period

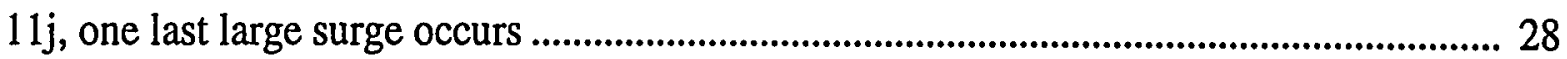

$11 \mathrm{k}$ The glass then finally separates from the pour spout knife-edge.................................... 28

$11 \mathrm{k}$ and 111 , one can see a second stream swing from side to side behind the main stream. This is similar to what was observed in the DWPF Pour Spout

12a-12f show some video clips of the glass stream as it swings backwards and forwards repeatedly during this test. The last figure shows multiple streams resulting from the last large wick

13 Conceptual Design of Improved Inserts 
WSRC-TR-99-00232, Revision 0

\section{LIST OF ACRONYMS}

CETL: Clemson University's Environmental Technologies Laboratory

DWPF: Defense Waste Processing Facility

SCUREF: South Carolina Research and Educational Foundation

SRS: $\quad$ Savannah River Site

SRTC: $\quad$ Savannah River Technology Center

WSRC: $\quad$ Westinghouse Savannah River Company, Aiken, SC 
TTP SR1-6-WT-31

\author{
Milestone C.1-2 Report: Functional Test of Pour Spout Insert \\ and Knife-edge (U)
}

\author{
D.F. Bickford, D.C. Iverson, H.N. Guerrero, M.E. Smith, \\ E.K. Hansen, J.C. George, R.P. Singer
}

\title{
Westinghouse Savannah River Company Savannah River Site Aiken, South Carolina 29808
}

\section{INTRODUCTION}

During the first two years of radioactive operation of the Defense Waste Processing Facility (DWPF) process, several areas for improvement in melter design were identified [1]. Due to the need for a process that allows continuous melter operation, the down time associated with disruption to melter operation and pouring has significant cost impact. A major objective of this task is to address performance limitations and deficiencies identified by the user (DWPF) [2]. The actual testing is being performed at Clemson University's Environmental Technologies Laboratory (CETL) using a full DWPF size stirred melter. The task installed, tested and operated the melter, including design, construction and operation of a full scale simulated DWPF riser and pour spout.

In preparation for vitrification, the radioactive feed is chemically processed using various acids. Borosilicate frit is blended with the processed feed and then continuously fed

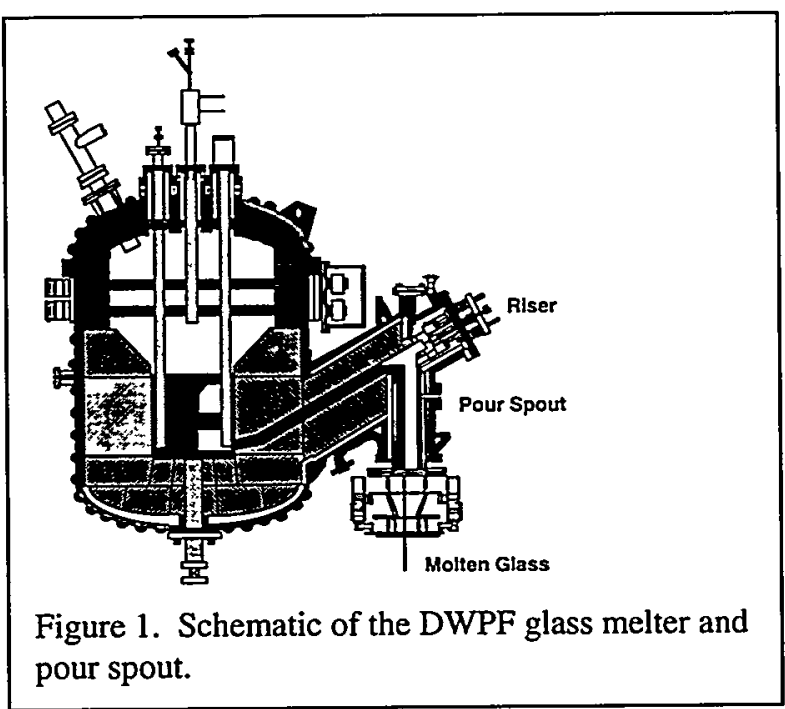


under normal operating conditions to the melter (Figure 1). The melt pool temperature is maintained at approximately $1150^{\circ} \mathrm{C}$. Pouring rates are nominally $82 \mathrm{keg}$ per hour $(180 \mathrm{lbs} / \mathrm{hr})$.

Normally molten glass flows over the riser and down the side of the pour spout closest to the melter. Two knife-edges are machined into the pour spout to provide a release point for the molten glass stream. The Inconel $690^{\mathrm{TM}}$ pour spout is not removable and therefore, failure of this component would result in the removal of the entire melter. External heaters are used to keep this region of the pour spout between 1000 and $1150^{\circ} \mathrm{C}$. The molten glass free falls from the knife-edge into the stainless canister below. In the DWPF as the knifeedges degraded the glass stream began to waver and wick down the side of the pour spout resulting in partial blockage in the bellows just above the canister. Glass that had built up on the knife-edges was initially removed by remote mechanical cleaning. However, the pour stream instability problem worsened. Thus, a removable Inconel $690^{\mathrm{TM}}$ insert containing a new knife-edge was developed and placed into the pour spout (Figure 2a). An Inconel $690^{\mathrm{TM}}$ retaining ring with three Inconel MA 758 pins were used to hold the insert in the pour spout (Figure $2 \mathrm{~b}$ ). Special tools were developed to remotely install this component into the pour spout between the upper and lower knife-edges. The upper knife-edge was used as a sealing surface. The insert was a key element in resolving the pour stream instability problems thus restoring glass production to design rates.

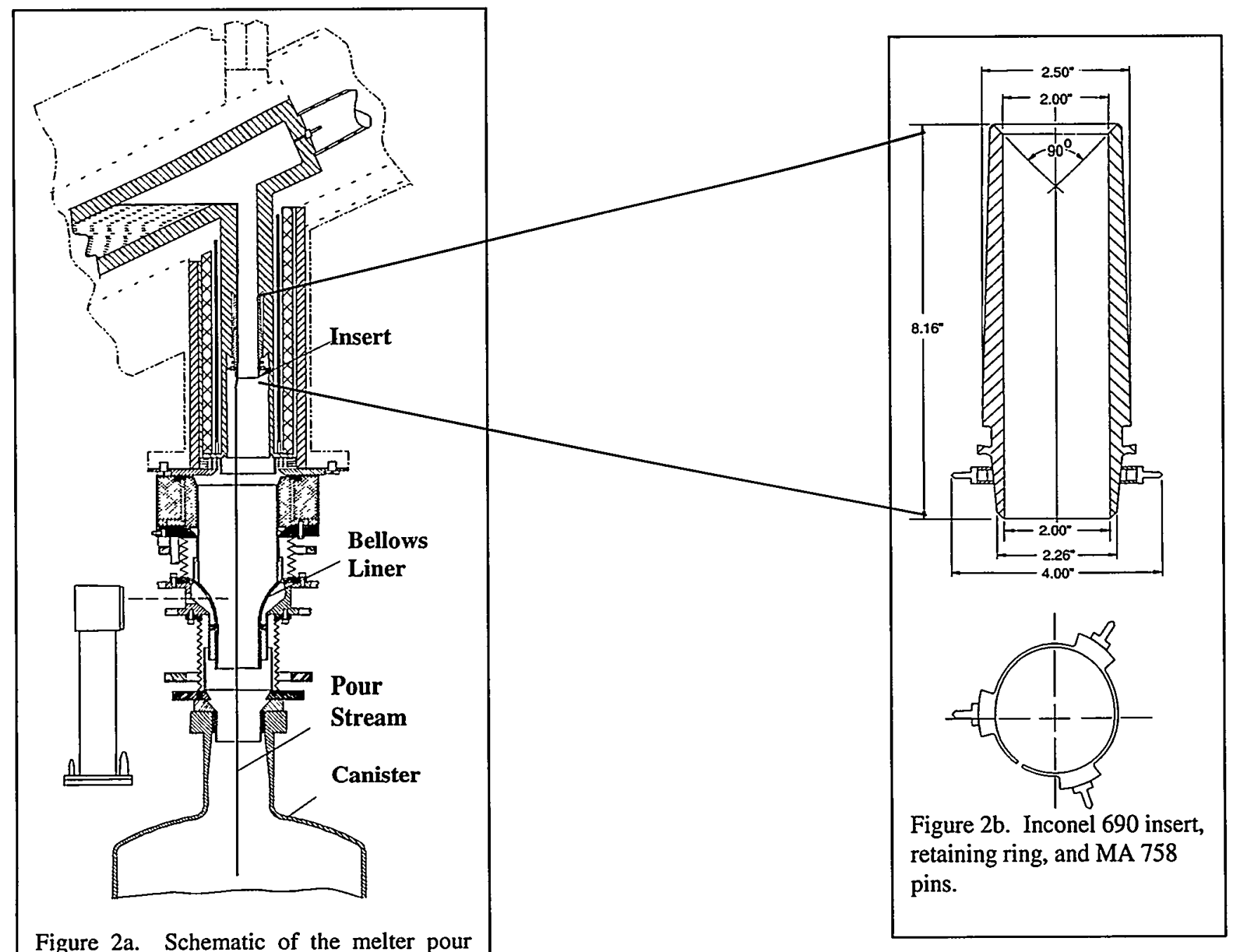
spout showing removable insert installed between upper and lower knife's edges. 
A Task Technical and Quality Assurance (TT\&QA) Plan and Experimental Test Plan $[3,4]$ detailing the task objectives, quality assurance, documentation, and responsibilities for the Improve Performance of HLW Melter Test have been written and approved. The Experimental Test Plan defines the functional performance requirements of the stirred melter and the acceptance criteria for the test.

\section{DWPF Riser/Pour Spout Design}

To conduct the necessary tests, a DWPF Pour Spout Test stand has been installed below the Superheater pour valve of the stirred melter.

The Riser section of the Riser/Pour Spout collects melted glass from the Melting Chamber and conducts it up an incline to the Pour Spout Section. The Pour Spout Section glass flows down into the canister, where the glass cools and hardens.

The major design objective of the Riser/Pour Spout is to fail safe, i.e., it is better to have operating failure modes which retain the glass in the melter than to have uncontrolled leakage of glass out of the melter. The pour control stream operated on the basis that a failure in the control equipment will stop the glass flow, rather than over filling the can. This is accomplished by sensing the plenum pressure (gas pressure) in the top of the melt chamber, and pulling a partial vacuum on the canisters. This partial vacuum draws glass up the riser, where it falls over into the pour section. The intention is then for the glass to separate from the pour spout metal at a knife-edge cut into the pour spout, and to fall directly into the can. The Normal Disengagement Point is the point of the knife-edge closest to the Melter Chamber, i.e., directly above the center point of the canister. The bellows section is replaceable and contains a Bellows Liner which is intended to guide stray glass back to the canister. The Bellows Liner is relatively simple to clean in place or remove if it becomes damaged. After passing through the Bellows Liner the glass drops through the Canister Throat Protector into the canister. The Throat Protector keeps the underlying metal clean to assure a quality canister closure weld.

The Riser Section contains a sealed-at-the-bottom annulus of Inconel $690^{\mathrm{TM}}$ (Inconel $690^{\mathrm{TM}}$ is the only nonplatinum group metal which can withstand exposure to molten glass and air for the required time of 2-8 years). Inside of the annulus are electrically insulating ceramic tubes and a serpentine shaped electrical heater element machined from a plate of Inconel $690^{\mathrm{TM}}$. The Riser section has similar construction. The heater elements are necessary to control the viscosity of the glass. The heaters are also necessary to keep the glass above its liquidus temperature. Staying above the liquidus temperature is necessary to prevent material dissolved in the glass from coming out as crystalline deposits which can plug the passages or disturb the normal flow of the glass. Crystalline spinels $\left[(\mathrm{Ni}, \mathrm{Fe})\left(\mathrm{Fe}, \mathrm{Cr}_{3} \mathrm{O}_{4}\right)\right]$ have been found in the upper section of the DWPF pour spout, indicating that this section is not always above the liquidus. The current Riser/Pour Spout design has temperature gradients resulting from end effects of the serpentine heaters, and high thermal losses where the Riser/Pour Spout are joined.

\section{Full-Scale DWPF Melter Pour Spout Test Stand}

The full-scale DWPF Stirred Melter Pour spout Test Stand was installed at Clemson University via a South Carolina Research and Educational Foundation (SCUREF) contract. It is located at the Clemson Environmental Technologies Laboratory (CETL). The stirred melter has a full-scale DWPF riser and pour spout attached to it to allow for glass pour rates equal to or greater than the DWPF Melter. This melter is the only pilot melter available to SRS which can give the high melt rates required.

The melter has two main sections. The glass melting occurs in the primary pot. This pot is made out of Inconel $690^{\mathrm{TM}}$ and acts as one of the electrodes. It is a three foot by three foot container five feet tall. An Inconel $690^{\mathrm{TM}}$ agitator is inserted into the glass pool and rotates up to $450 \mathrm{rpm}$. Agitation forces the unmelted feed down into the $1050^{\circ} \mathrm{C}$ melt pool, thereby increasing the contact area between the glass and the feed and 
thus greatly increasing the melt rate. Higher temperatures are possible but are limited by various means because of uncertainties caused by possible thermal creep of the primary pot. The agitator is the second electrode. The glass is heated by passing current through the glass (joule heating) via these two electrodes (melt pot and agitator). External heaters are also in place to aid in the heatup of the melter and to heat the vapor space for a higher melt rate.

Due to the need to ensure glass durability and provide complete liberation of bubbles from HLW glass to preclude a porous glass product, the melter was designed to deliver glass from the primary pot to a Superheater operated at $1150^{\circ} \mathrm{C}$ (with a glass residence time of a least 4 hours). The Superheater, made of Inconel $690^{\mathrm{TM}}$ as well, is externally heated and can be operated at this higher temperature because of the smaller height (six inches) and the overall shape of the Superheater. These two factors minimize the mechanical loads on the Inconel $690^{\mathrm{TM}}$ in the Superheater.

The design features incorporated into the DWPF Stirred Melter are based on the premise that 1) the glass making process and particularly any glass contact mechanisms will be demonstrated and 2) remoteability features requiring only design (with no experimentation required to verify the design) will be demonstrated. All of these features may not be needed for the pour tests, but are given below to allow for a better understanding of the test stand:

- The design melt rate is 240 pounds per hour (pph) for slurry feeding at 40 weight percent solids (pour rates may be more that twice this for some test),

- Inconel $690^{\mathrm{TM}}$ is the reference material of construction for all glass contact areas,

- the distance between the main pot pour valve and the superheater drain valve is prototypic of the existing DWPF Melter design, (the relative elevation difference is not prototypic),

- the superheater is designed to provide a glass residence time of 4 hours at $1150^{\circ} \mathrm{C}$ to meet the glass durability requirements,

- the melter cooling system is designed to provide melter surface temperatures less than $50^{\circ} \mathrm{C}$ to match the existing DWPF Melter design criteria,

- the agitator shaft changer for "remote" removal of the agitator was included,

- the melter is designed to facilitate maintenance/replacement of either the primary melter or the superheater because the superheater can be displaced 34 inches (while at operating temperature) to allow the primary melter or the superheater to be taken out of service, and

- due to cost constraints, the melter is not designed for remote removal of the melter pot.

A full-scale DWPF riser and pour spout is heated with external resistance heaters. Temperatures are monitored by multiple thermocouples. Glass is poured out of this superheater pour valve and into the riser/pour spout at rates equal to or exceeding the nominal DWPF rate of $240 \mathrm{pph}$. A canister will be located below the pour spout to collect the molten glass. This unit functions as the molten glass supply, flow control and temperature control. Added to the Superheater is a riser and pour spout with the same internal dimensions as the DWPF riser and pour spout. This full size riser and pour spout have observation ports to allow viewing of testing under realistic DWPF conditions. The melter feed is glass cullet from DWPF cold runs or large scale pilot tests at TNX. Some of the glass will be from runs which had noble metals in the feed. This glass is crushed and reused as melter feed. A wet off-gas system will not be required, although the melter off-gas is vented to the existing exhaust system at the CETL.

The various heater zones on the melter are controlled by Watlow ${ }^{\mathrm{TM}}$ controllers. These controllers have dual thermocouple inputs. If the primary thermocouple fails, the secondary thermocouple is used. The controllers can be run in manual or automatic (temperature setpoint mode). The controllers can be set to alarm for out of specification temperatures and programmed to limit the percent output allowed, to prevent overheating of the various portions of the melter and superheater. The controllers also have the capability of being remotely 
controlled (setpoint changes), although this is not planned for work at Clemson. A monitor is available which can be used to view the various melter parameters.

Installation and checkout of the stirred melter and the pour spout are complete. This report discusses the outline of that program and a preliminary analysis of the results of spout testing.

The following four pages show pictures of the pour spout, the insert and the installation images of the pout spout.

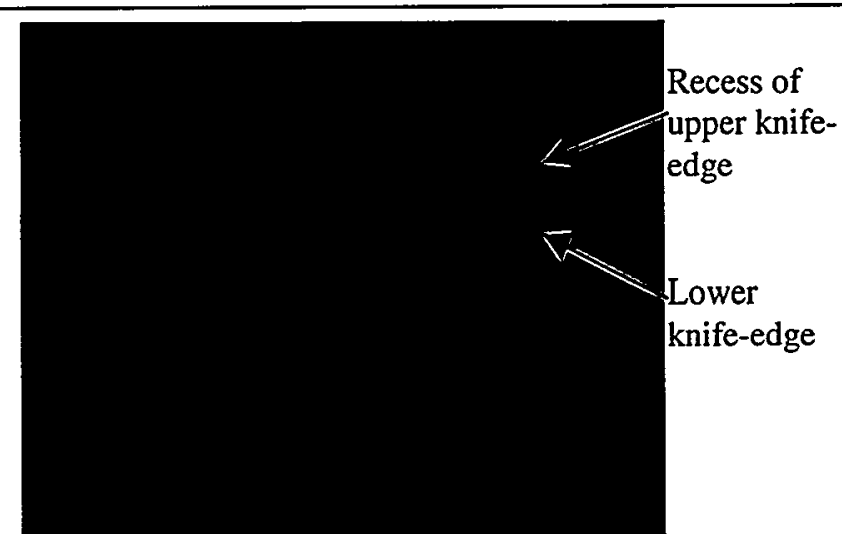

High resolution electronic Camera image looking up at $1150^{\circ} \mathrm{C}$ upper knife-edges has near-as-machined finish at the recess of the knife-edge, as does lower knife-edge.

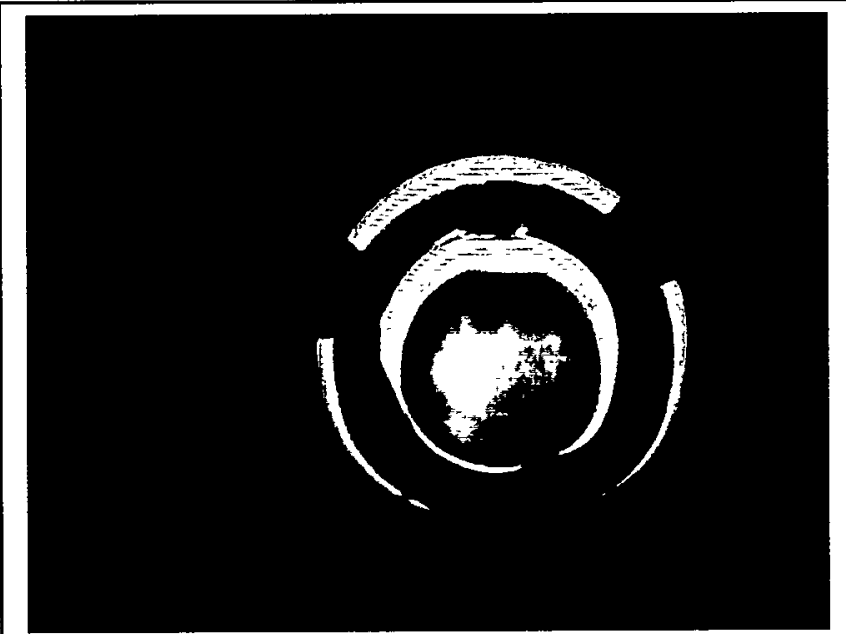

Insert installed in spout and at operating temperature. Note accumulated glass in the insert, and that the insert is off center.

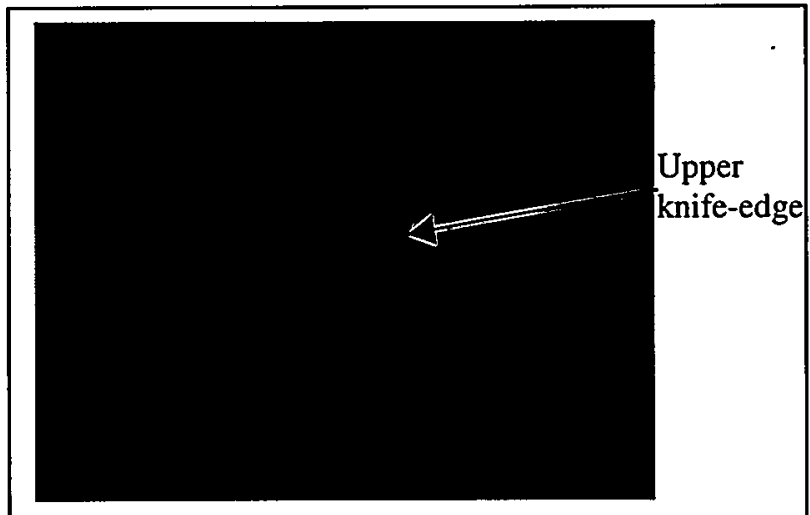

High resolution electronic camera image looking up spout at $1150^{\circ} \mathrm{C}$ showing near-as-machined condition of upper knife-edge.

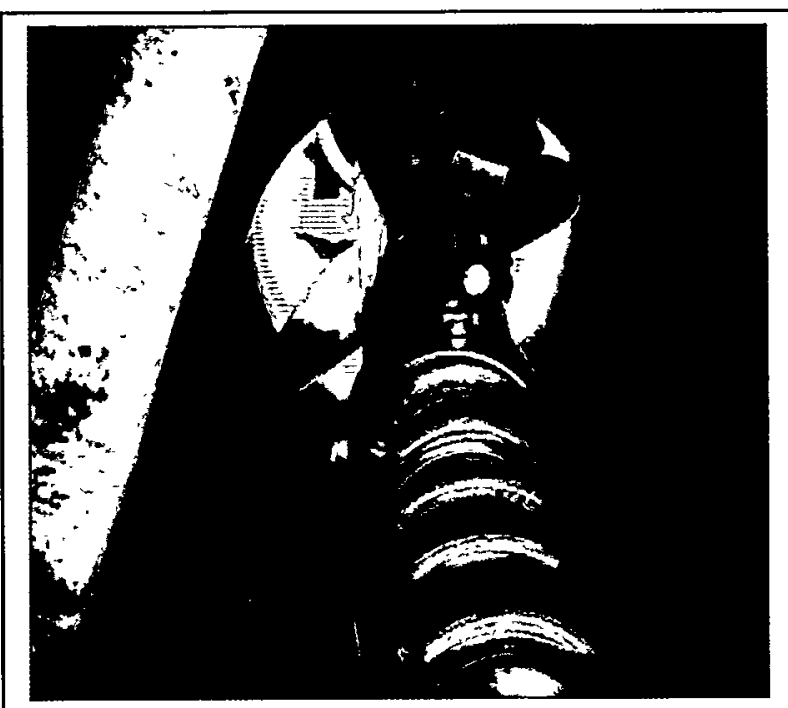

Replaceable insert being installed in the test spout 

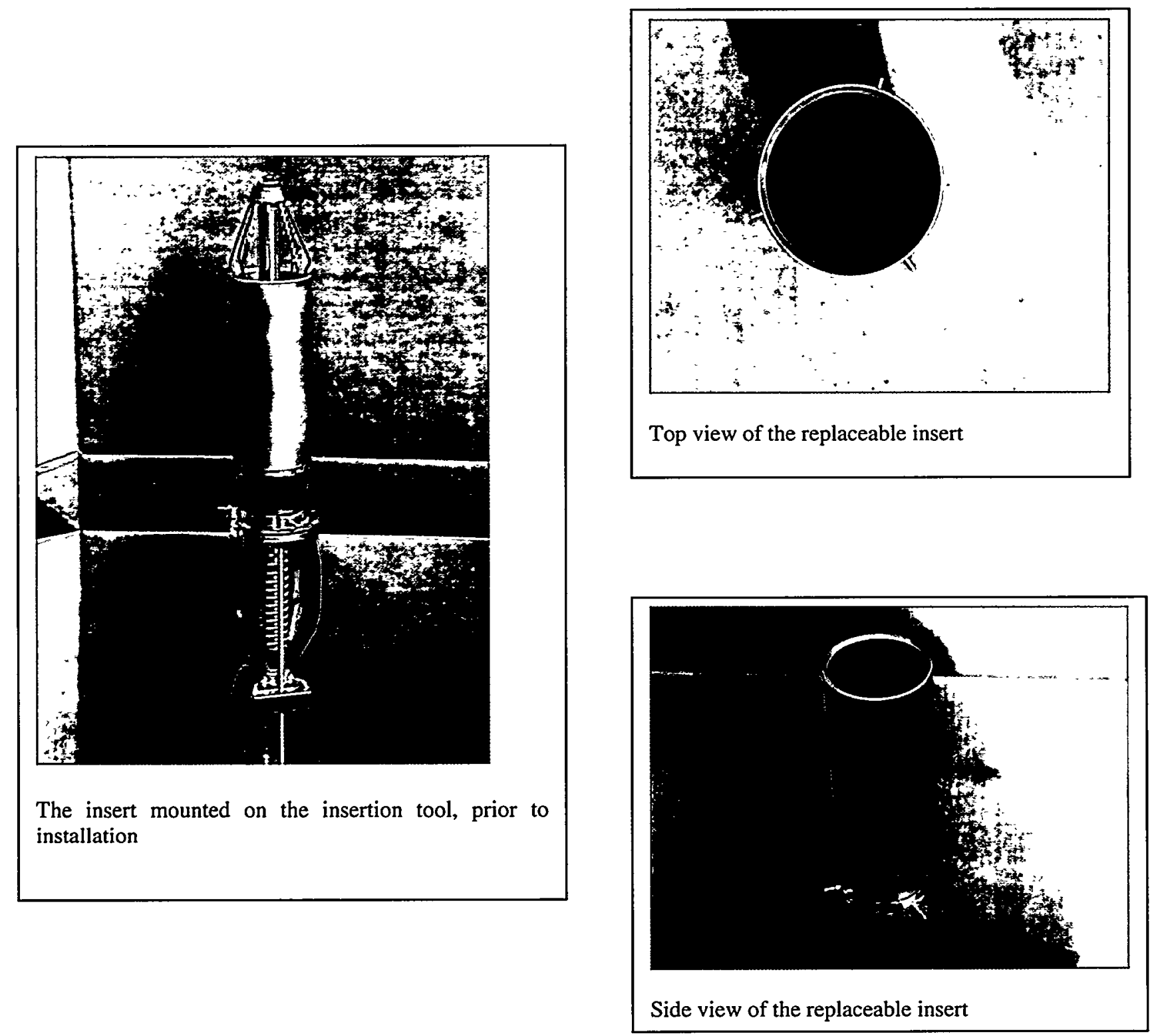


\section{ISO Therm @ $1175^{\circ} \mathrm{C}$}

\section{$1179^{\circ} \mathrm{C}$}

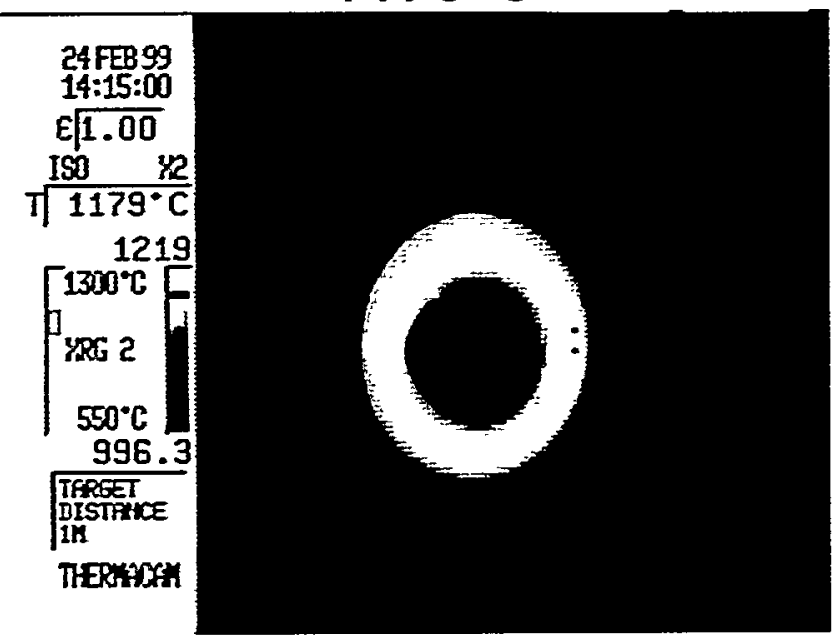

\section{$1153^{\circ} \mathrm{C}$}

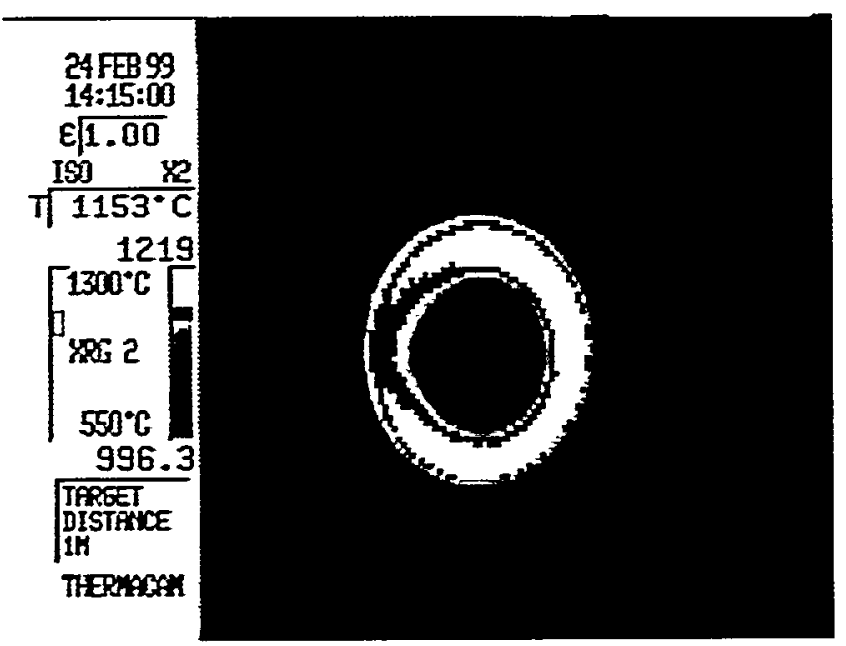

\section{$1106^{\circ} \mathrm{C}$}

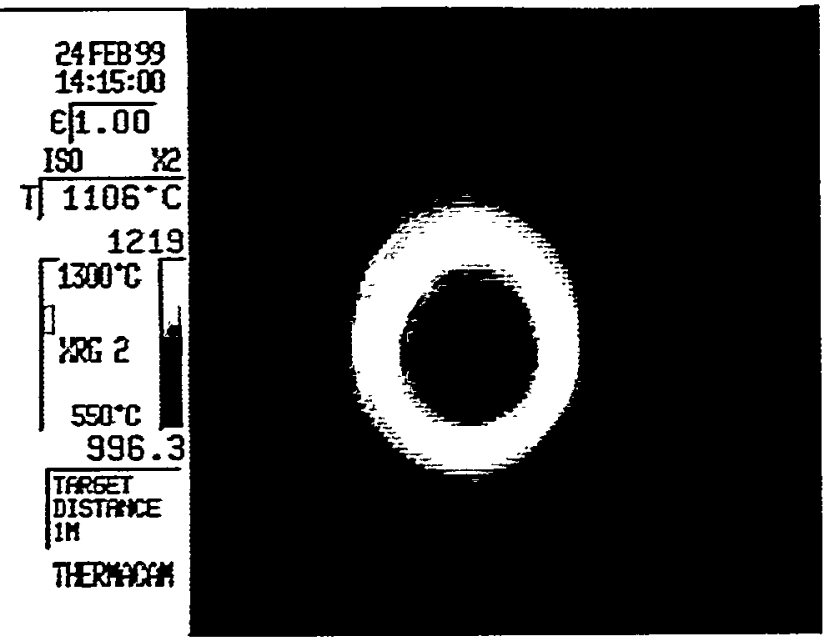

$1082^{\circ} \mathrm{C}$

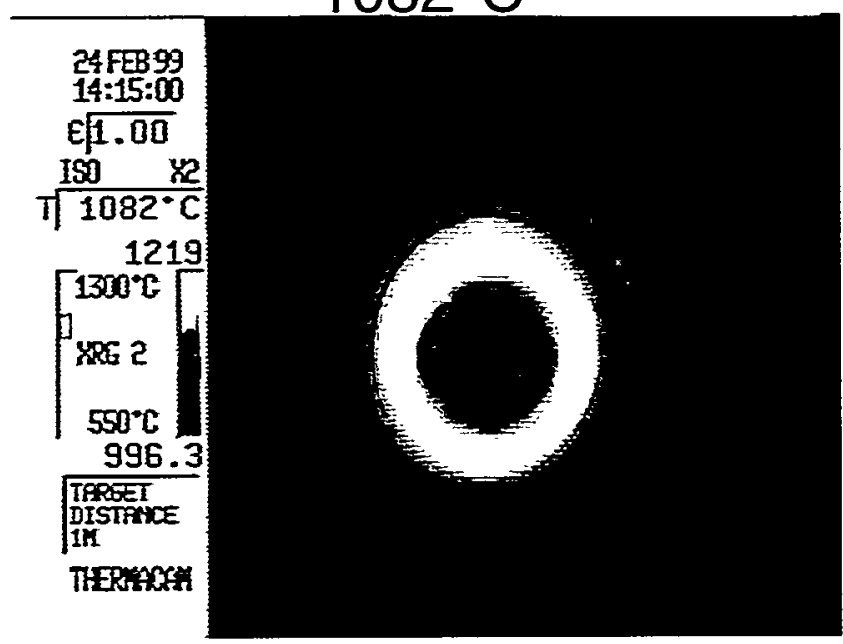

$1049^{\circ} \mathrm{C}$

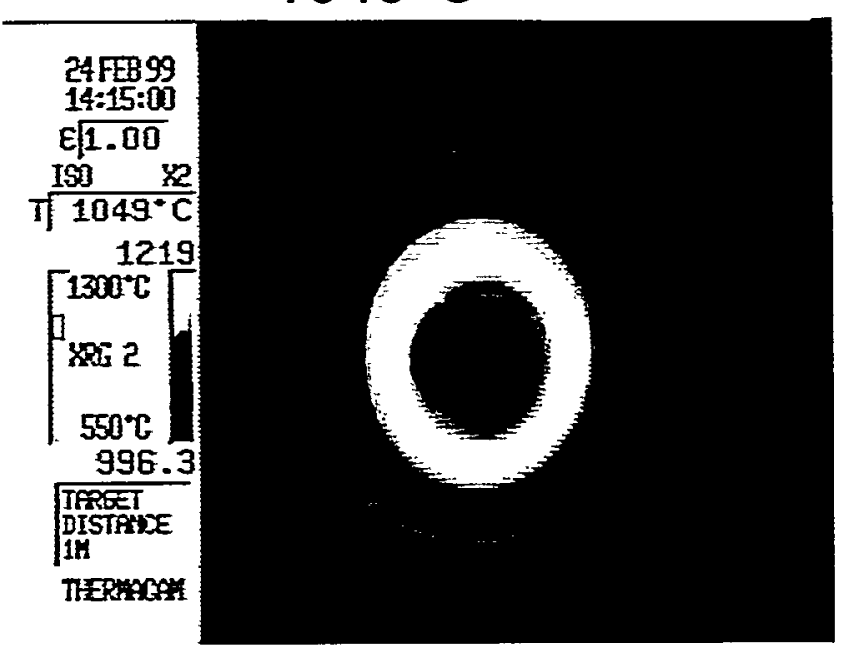

Temperature gradients in pour spout:

False color thermal images of the pour spout at operating temperatures, without the insert. The color scale on each picture indicates the temperature range. The region of the picture shown in black is at temperature T. Note uniformity of temperature around the circumference, and high operating temperate at the wall of the spout. The apparent low temperature at the top of the spout (center of picture) is caused by observing through a viewing port. 


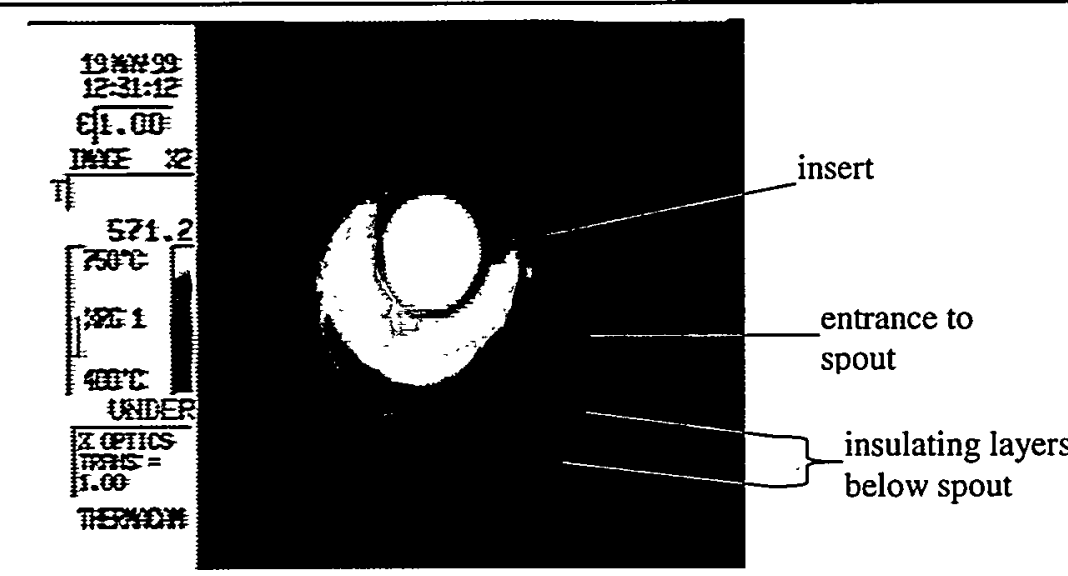

Thermal imaging viewing up the spout.
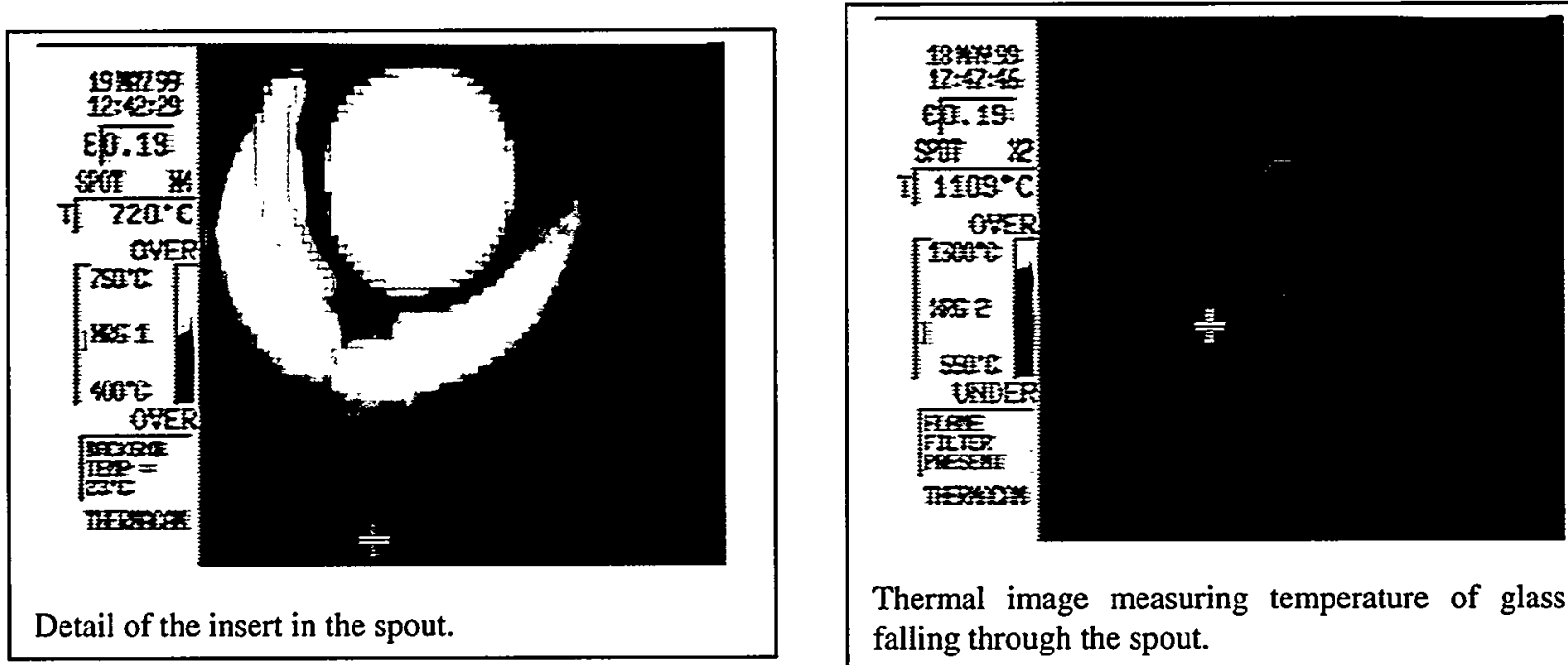

Thermal image measuring temperature of glass falling through the spout.

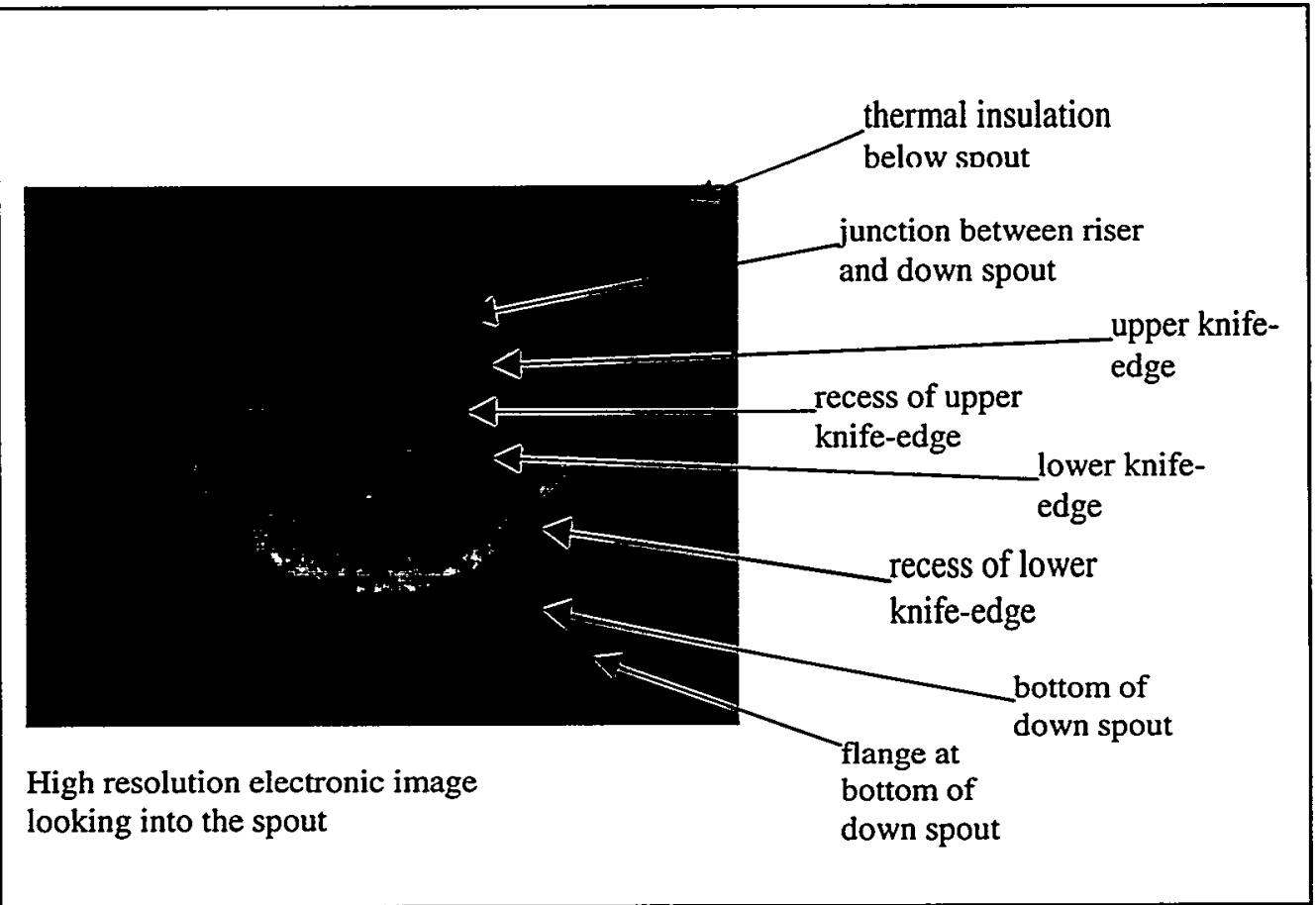




\section{TEST PROGRAM}

A comprehensive test program is being performed with the objective of improving operability issues by evaluating alternative critical component designs. Testing will be conducted on spout and glass drain valves. Actual test sequence depends upon priorities established by DWPF.

- General operability of Stirred Melter, agitator wear and sealing issues

This task is partly complete. The Stirred melter is fully operational, but has limited operating time. Most of the Stirred Melter design operated very well. However, based on glass volume the melter is a 27X scale up of the largest prototype tested ( $3 \mathrm{X}$ linear scale up factor). Therefore several components required modification or replacement, including buss bars and electrical brushes (see pictures below) carrying electrical current to the agitator, grounding and ground fault interruption equipment, heaters to the Superheater (hot glass hold tank), Superheater pour spout, and glass level detection.

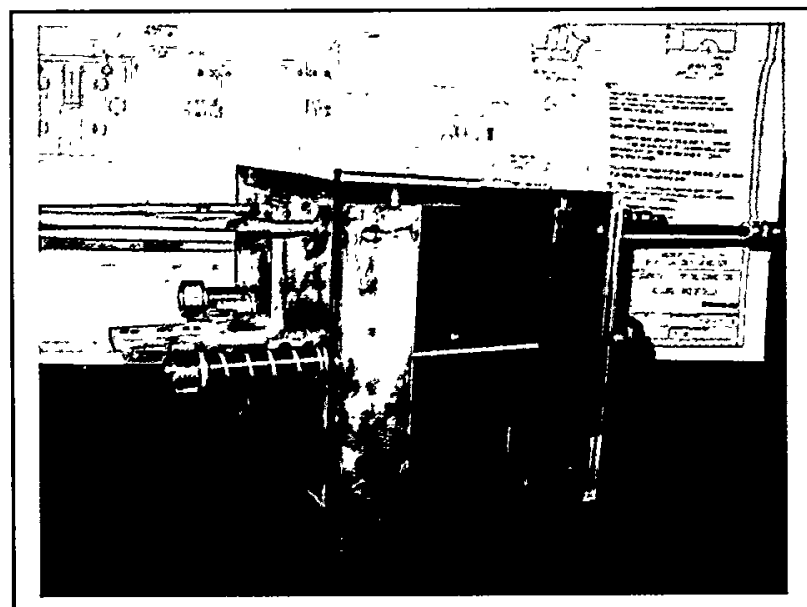

The two assembled electrical brushes used to replace the supplied buss bar and connectors.

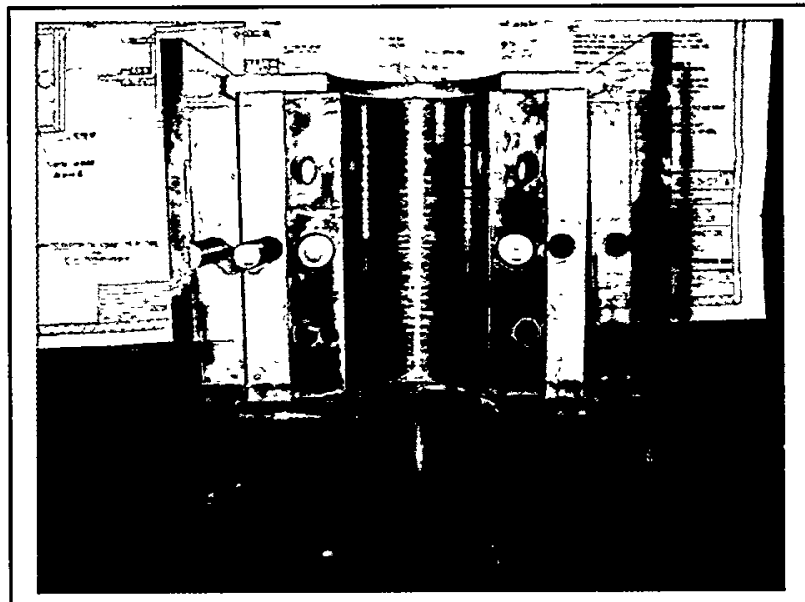

Inside of the new brush assembly showing the graphite electrical brush supported by a copper support.

- Startup, hold and drain testing of Stirred Melter, with operating procedures

All required operating procedures are approved. The stirred melter has been through startup testing. As constructed, the main melting tank (Primary Tank) and the Superheater are heated with resistance heaters. The Primary Tank heaters are sufficient to heat the tank and glass to a temperature where joule heating of the glass is effective. However, the Superheater power was inadequate as supplied to achieve the required glass holding temperature of $1150^{\circ} \mathrm{C}$. Additional heaters were added under the tank and beside the Superheater drain and pour valves, but the maximum temperature remains marginal in the Superheater, requiring major redesign to conform to DWPF requirements. The drains have been tested. As a result, additional heaters have been added to the Superheater drain. The pour valve inlet has been shortened to enhance glass flow and achieve better pour rates. Primary Tank drain, as designed, is acceptable for flow control; however, heating in this area is inadequate and has required auxiliary gas heating to operate. The Primary Tank spout has operated satisfactory. However, the spout had a restrictive opening which slows glass flow and causes excessive glass head build up in the Primary Tank. 
WSRC-TR-99-00232, Rev. 0

Main Pot Heat Up 6/21/99

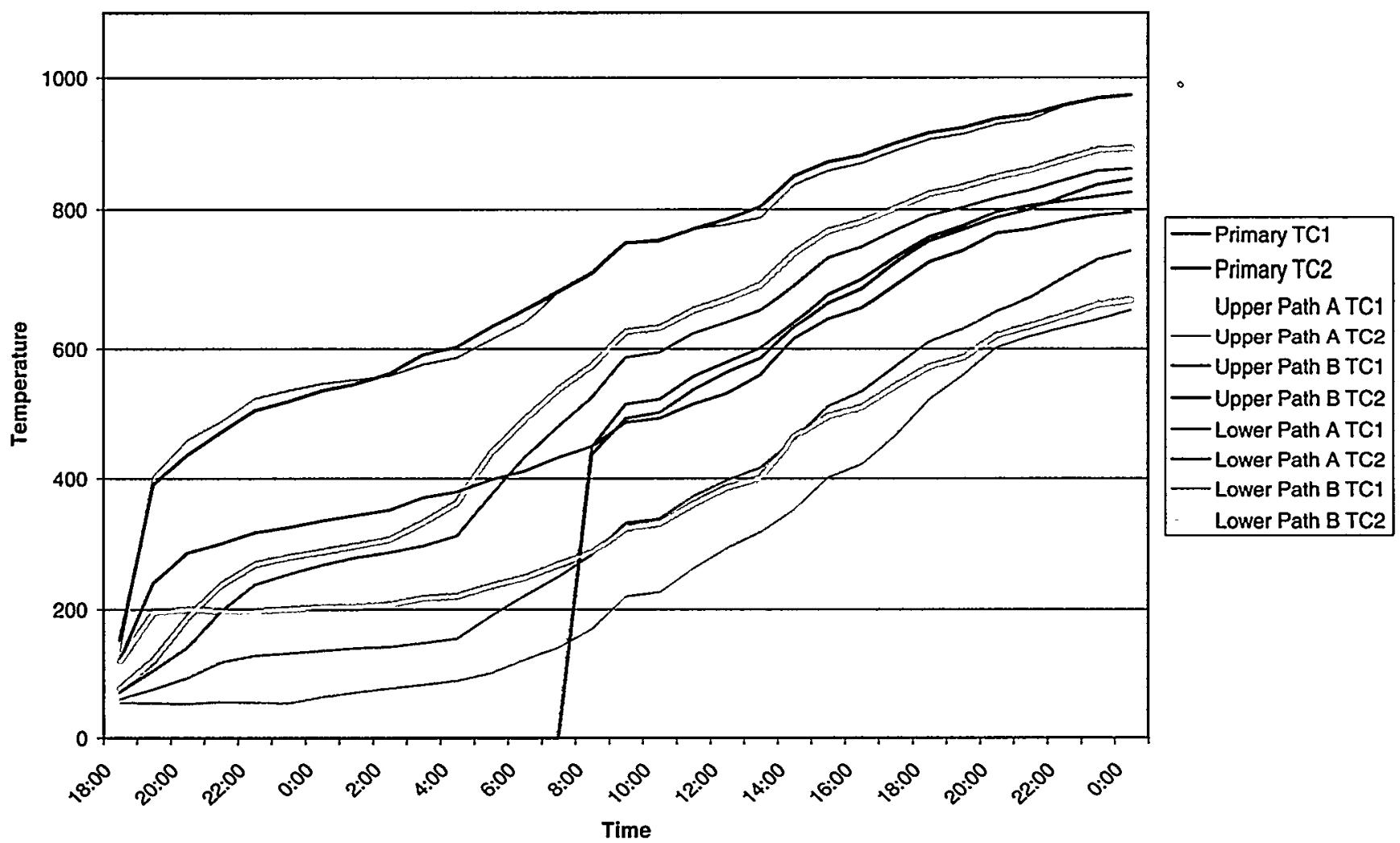


WSRC-TR-99-00232, Rev. 0

Main Pot 6/21/99

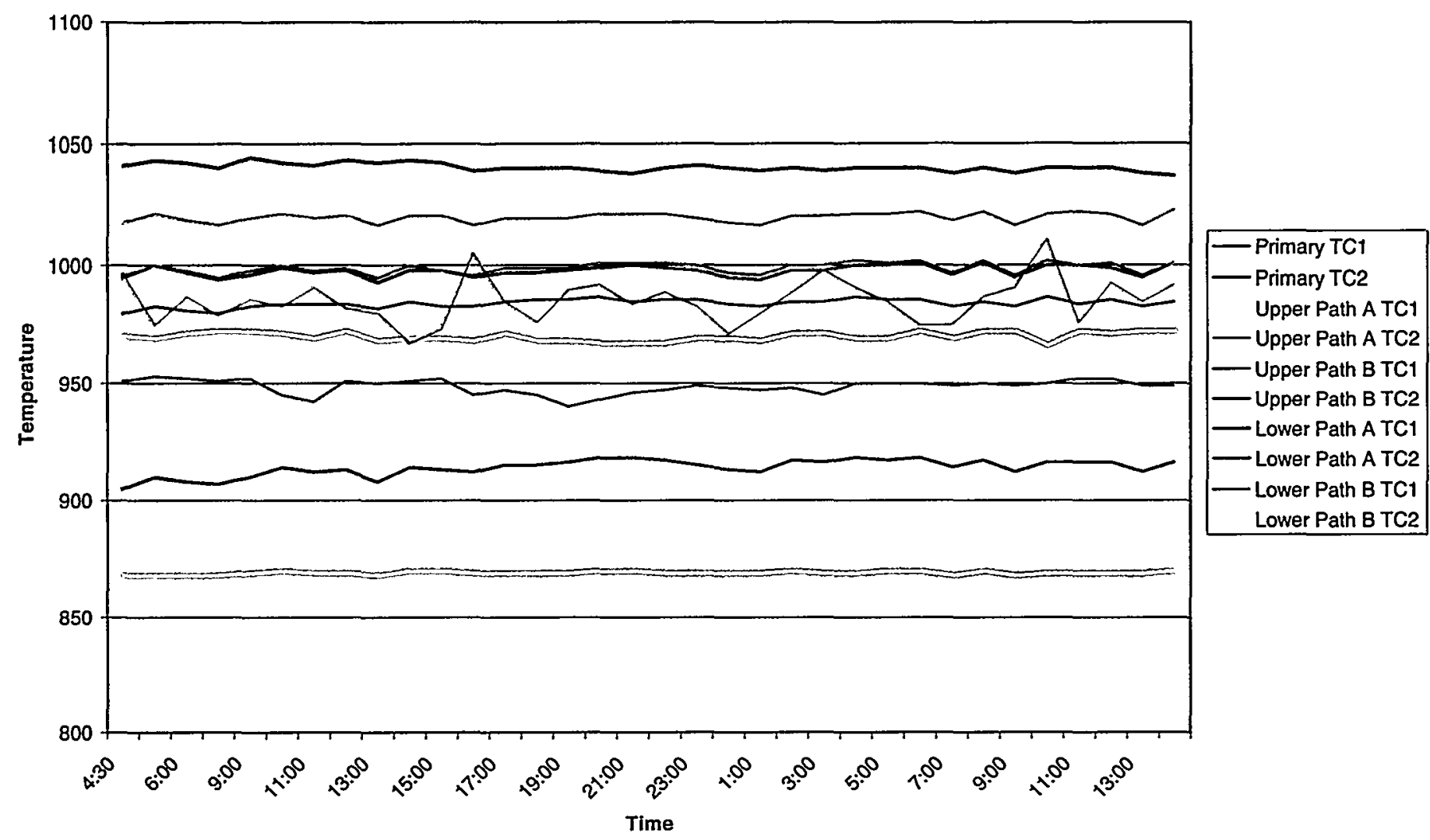

Melter Primary Tank temperatures at steady state without joule heat. The primary thermocouples are inside of the Tank. TC1 thermocouples are adjacent to the tank. TC2 thermocouples are adjacent to resistance heaters. The heaters are sufficient to heat the glass to start joule heating, but will not maintain the glass at the operating temperature of $1050^{\circ} \mathrm{C}$. 
WSRC-TR-99-00232, Rev. 0

SuperHeater Checkout 5/17/99

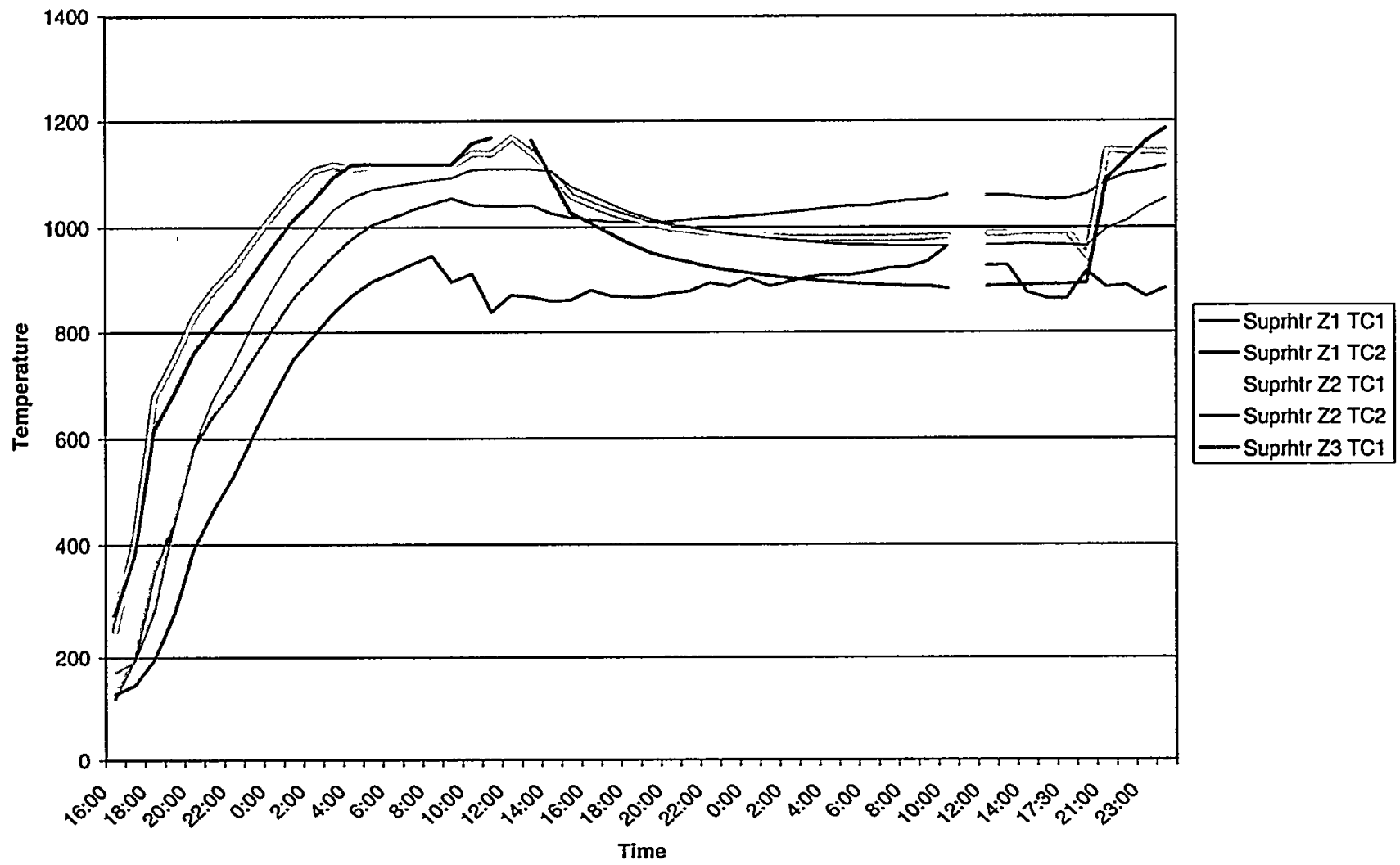

In the Superheater TC1 thermocouples are adjacent to heaters and TC2 thermocouples are adjacent to the tank. The heaters are not sufficient to uniformly to heat the glass to $1150^{\circ} \mathrm{C}$. 
Superheater 6/21/99

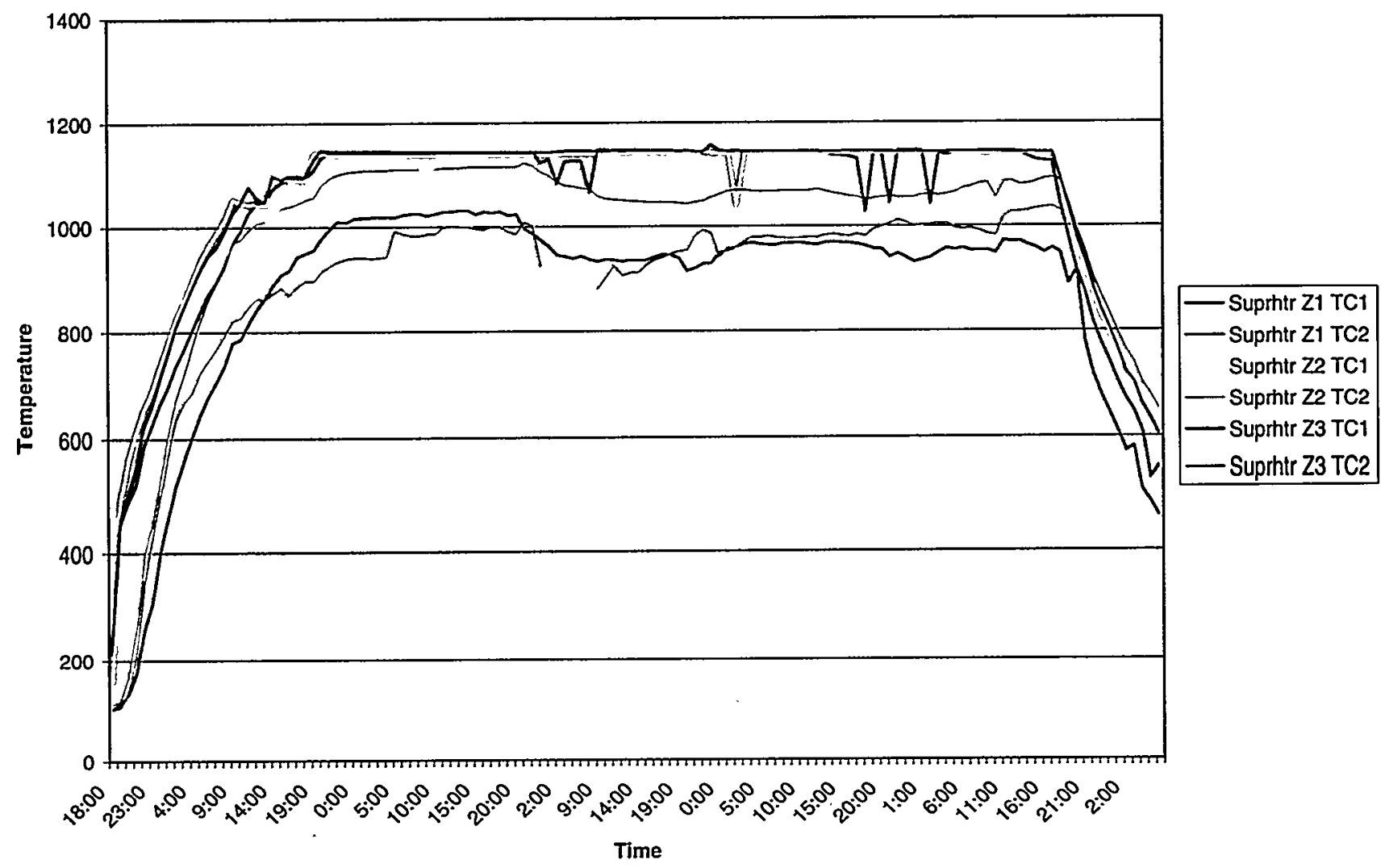

Superheater temperatures after installation of auxiliary heaters. Glass temperatures are more uniform but are below the desired $1150^{\circ} \mathrm{C}$. 


\section{Pour Spout Temperatures 6/22/99}

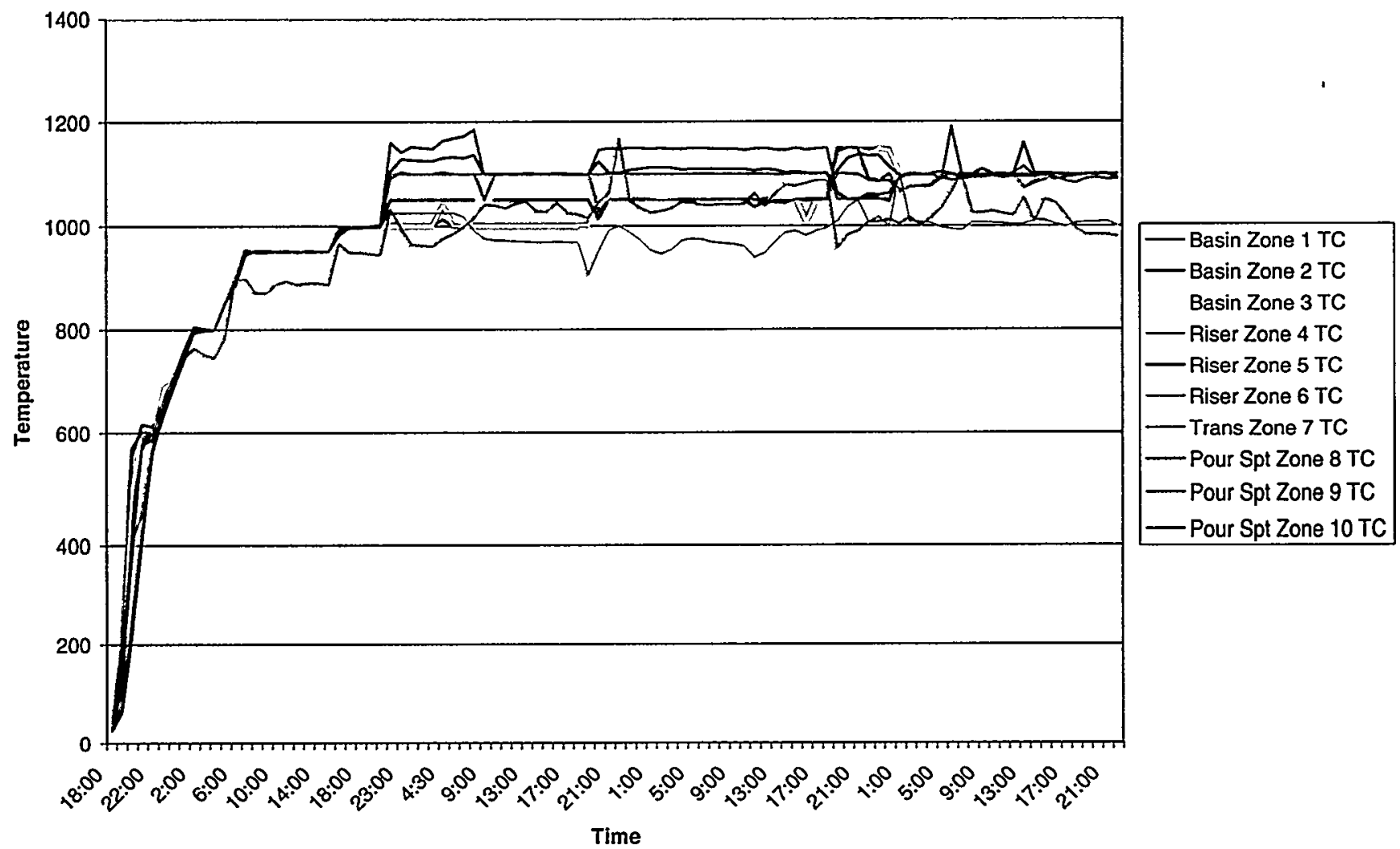

Temperatures of the DWPF test Riser and Pour spout set mimic the actual melter. 
Pour Spout 5/17/99

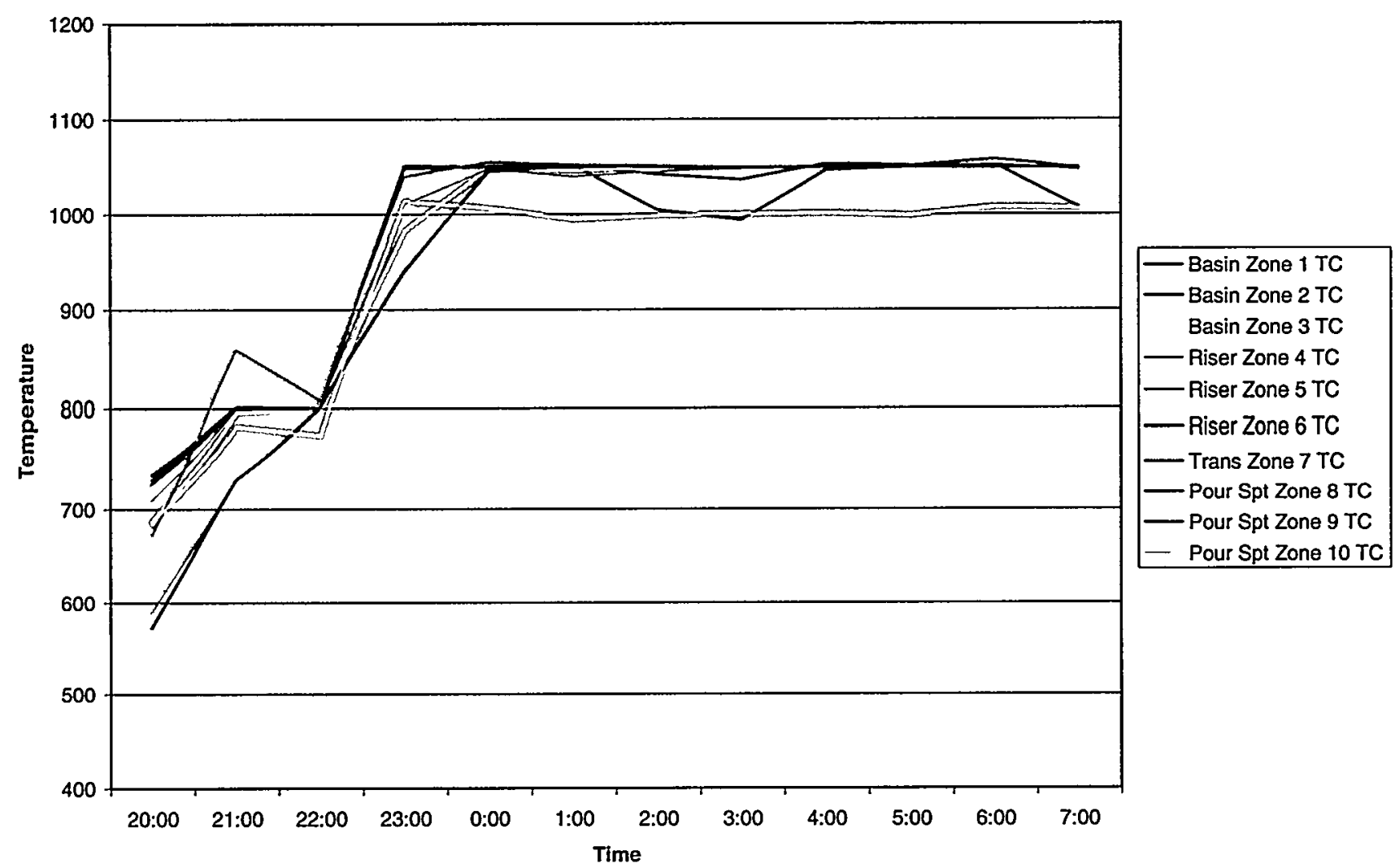

Temperatures in the DWPF test Riser and Pour Spout, $1050^{\circ} \mathrm{C}$ setpoint. The glass enters the holding basin at Zone 1 and enters the Riser at Zone 4, transitions to the Down Spout at Zone 7. The bottom of the spout is cooler because of radiative heat lose from the bottom. 
Drain Side 5/17/99

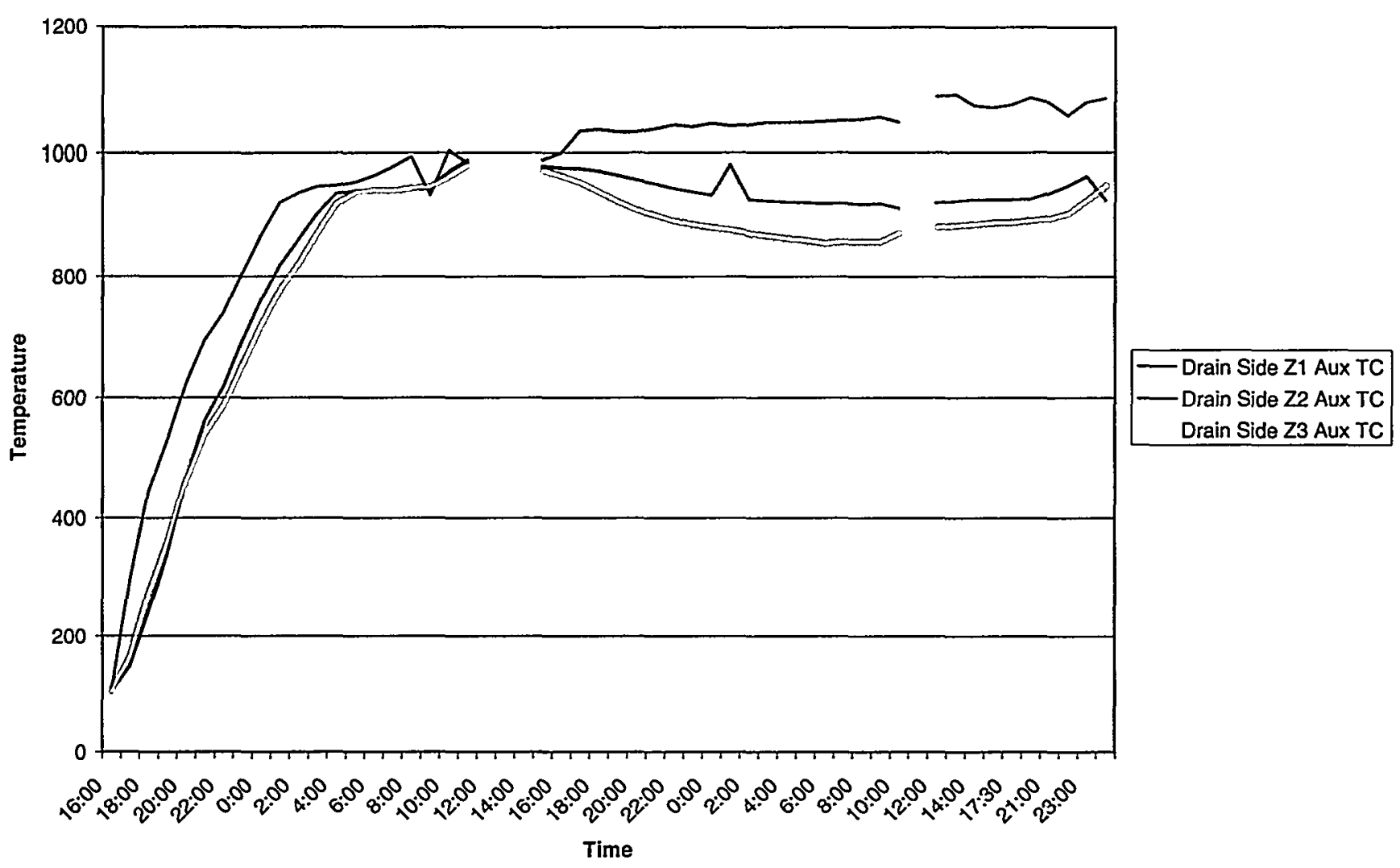

Temperatures of the auxiliary heaters installed to improve glass heating in the Superheater. (3 auxiliary heaters). 
- Comparison of melt rates with conventional melter (melt rate enhancement)

Melt rates in the tank with DWPF surrogate glass were above 800 pounds per hour with dry feed. This is approximately equivalent to 400 pound per hour with slurry feeding. This is well above the minimum design requirement of 228 pounds per hour. These tests were conducted at $2 / 3$ of the rated capacity of the power supply, indicating that still higher slurry feeding rates may be possible.

- Potential improvement list

Major operability issues were addressed by modification of the cooling water system, joule power system, and Superheater power system. Improvement is required in the Primary Tank spout and drain, and level detection and control. Major redesign and testing of the Superheater would be required for radioactive service.

- Remoteability evaluation

The compact modular design of the stirred melter appears suitable for high capacity remote radioactive service. Increased operating time is necessary to determine estimated life. A smaller Superheater with increased heater capacity and remotely replaceable thermocouples, and spout and drain heaters would be required. In the Primary Tank the Inconel $690^{\mathrm{TM}}$ should be separated from the resistance heaters, insulation and cooling water jacket by a secondary containment tank. The cooling water jacket around the Primary Tank and the Superheater do not appear to be required, and would simplify installation and operation.

\section{Pour Spout Tests}

Thermal-Hydraulic Parameter Tests with Nominal Knife-edge Geometry

- Effect of flow: 50 to $>250 \mathrm{lbs} / \mathrm{hr}$ (400 lbs/hr desired); nominal $228 \mathrm{lbs} / \mathrm{hr}$

Tests have been conducted at $20-400 \mathrm{lbs} / \mathrm{hr}$

While the Superheater pour and drain spouts have nearly identical designs, flow rates through the pour spout have been lower than desired. Auxiliary heaters have been added to this area of the Superheater. During testing it was noticed that the pour stream became erratic when the glass level was less than two inches high above the entrance to either of these flow control devices. Consequently, the stand pipe at the entrance to the pour spout was shortened to increase the hydraulic head at the entrance and permit a more fully developed flow.

- Effect of glass temperature: 950 to $1100^{\circ} \mathrm{C}$

Testing has been conducted with the maximum temperatures available with conservative settings of Superheater power assemblies. Apparent in-tank glass temperature of $1030^{\circ} \mathrm{C}$ was achieved with heater assemblies at $1175^{\circ} \mathrm{C}$. The simulated DWPF riser and pour spout mimics DWPF spout temperature gradients and follows the set points of the zone heaters. In the lower section of the spout high radiative heat loss causes glass to adhere to the spout. This is similar to the DWPF Melter. 
- Effect of glass/spout temperature difference

In addition to operations with glass and spout at nominal DWPF conditions, the system was tested with $1050^{\circ} \mathrm{C}$ spout and $1150^{\circ} \mathrm{C}$ glass, as well as $1150^{\circ} \mathrm{C}$ spout and $1050^{\circ} \mathrm{C}$ glass. Flow was generally more predictable with higher spout temperatures.

- Effect of pour spout temperature gradient

Temperature gradient measurements have been made in the spout with and without an insert. They have been measured with a thermocouple, similar to those used to characterize the DWPF spout, and by infrared thermography.

- Effect of transients

Several series of tests have been performed. Known masses of glass have been instantaneously added to the glass hold tank. The additions result in a step function increase of head pressure in the hold tank which is identical in effect to a decaying step function increase in pour pressure in the DWPF. In particular, the increase in pour rate has been seen to cause wicking, erratic behavior of the pour stream, and changes in the general flow pattern of the spout. The resulting transients were videotaped in the spout and are shown in Figures 3-12. 
Figure 3. Glass Stream Behavior Inside an Insert During a 7.8 lbs Surge (09:58-5/19/99)

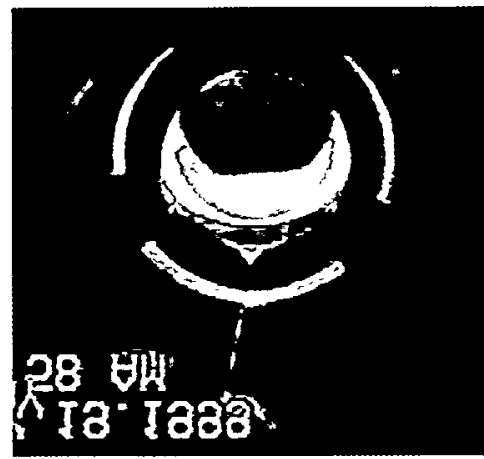

a

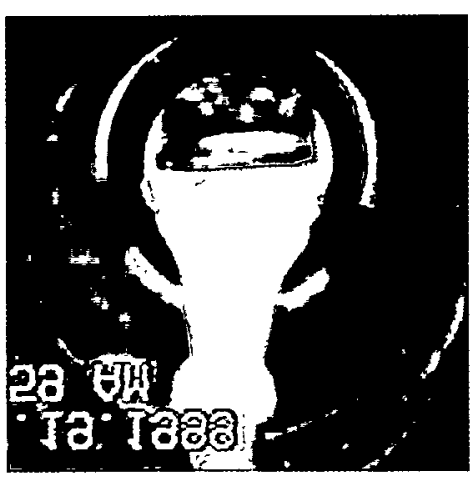

d

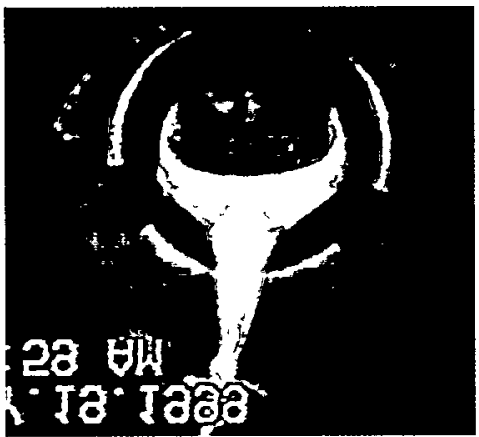

g

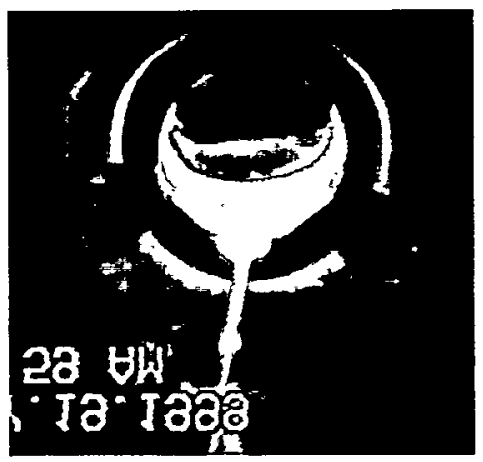

j

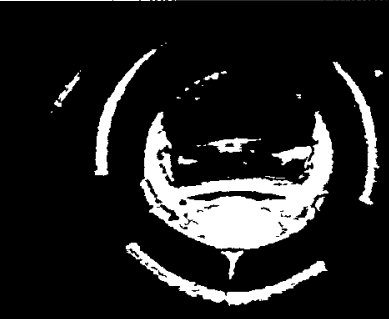

28 ता

Ta Taza

b

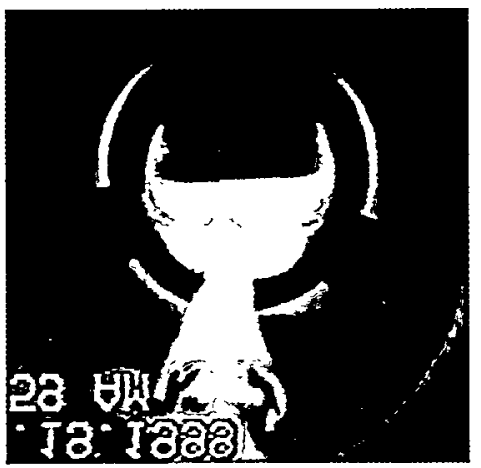

e

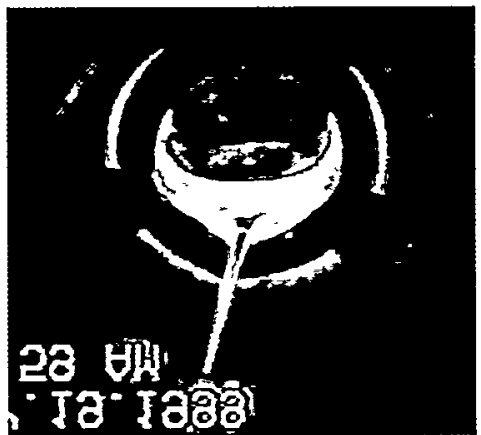

h

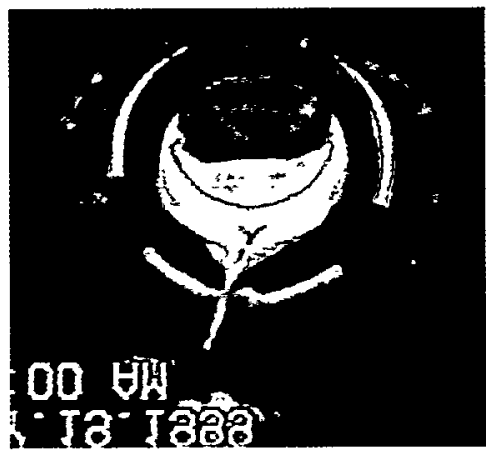

k

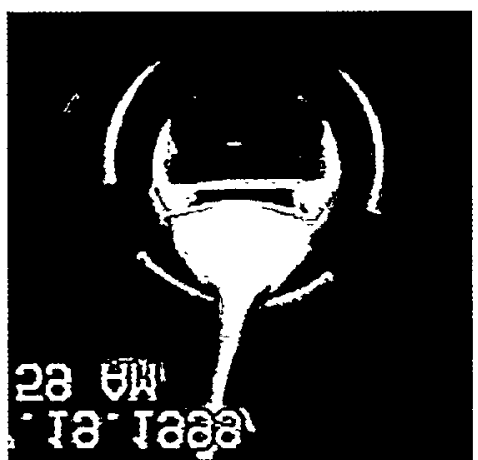

C

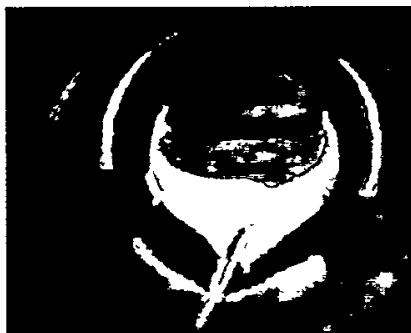

28 재

I0 T⿳⺈

$f$
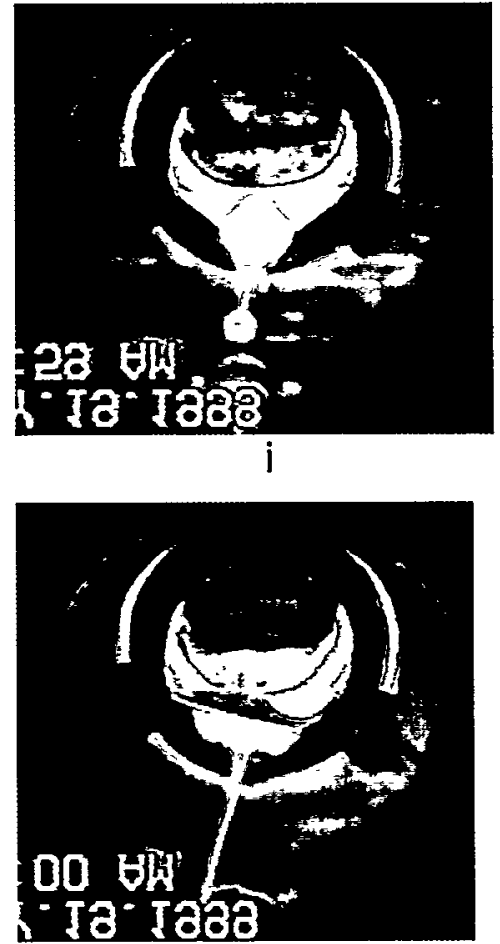
Figure 4. Glass Stream Behavior Inside an Insert

At $125 \mathrm{lbs} / \mathrm{hr}$ and $4 \mathrm{lbs}$ Surge (23:16-6/25/99)

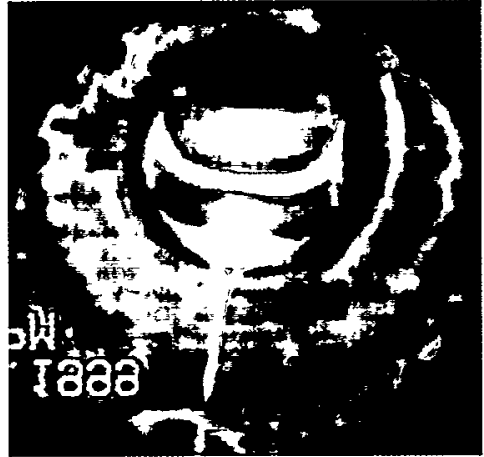

a

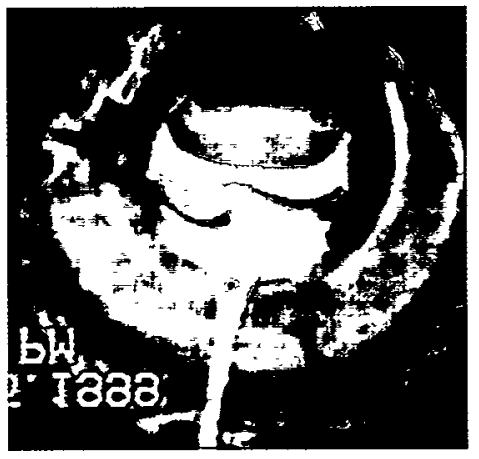

d

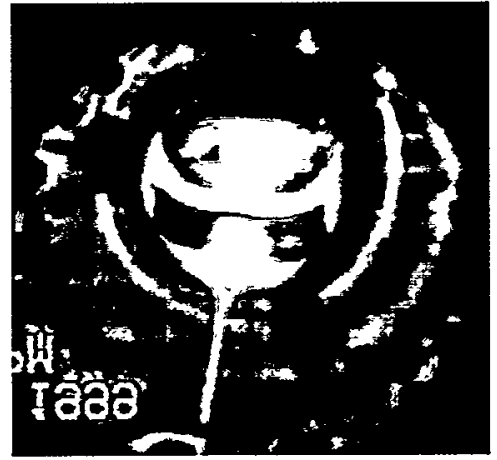

b

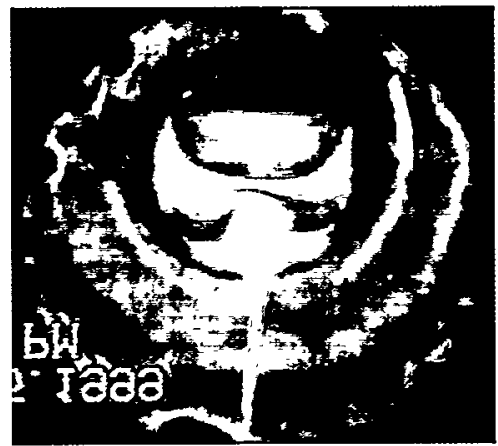

e

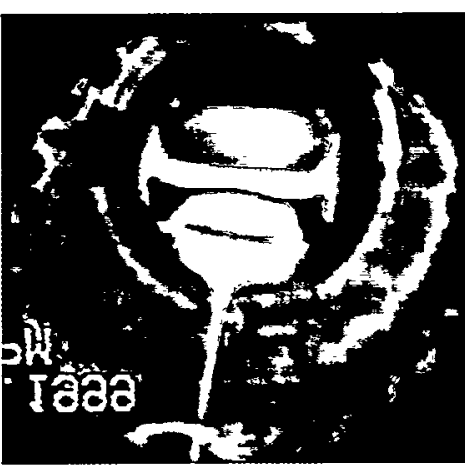

C

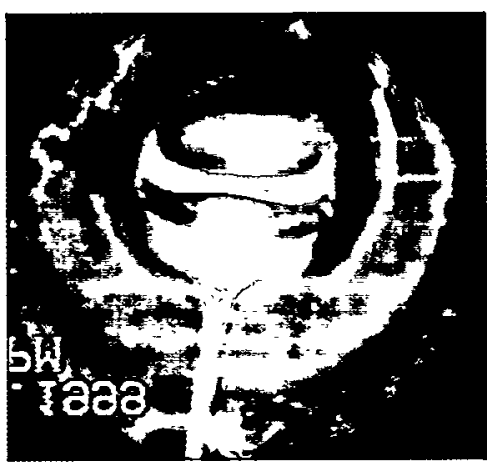

$f$

In this run, the steady state flow was $125 \mathrm{lbs} / \mathrm{hr}$. Figure $4 \mathrm{a}$ shows the position of the glass stream separation prior to the surge which is from the insert knife-edge. Figures $4 \mathrm{~b}$ and $4 \mathrm{c}$ show the progress of the surge front from a 4 pound glass chunk dropped into the reservoir at the pour spout and insert, respectively. The glass stream separating from the insert knife-edge grew in diameter (Figure 4d) moved slightly to the right and then moved back to center. There was no large movement of the glass stream evident from the side camera recording. 
Figure 5 Glass Stream Behavior Inside an Insert At $125 \mathrm{lbs} / \mathrm{hr}$ Flow and $8 \mathrm{lbs}$ Surge (23:25-6/25/99)

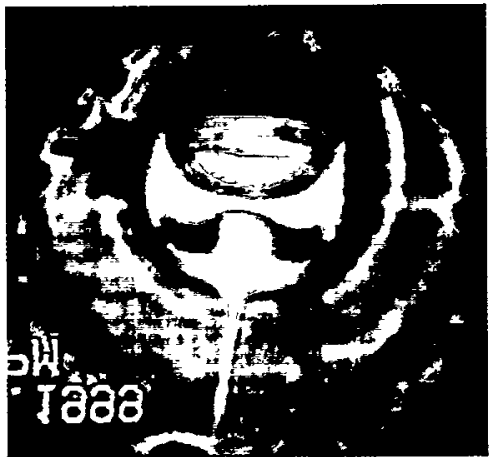

a

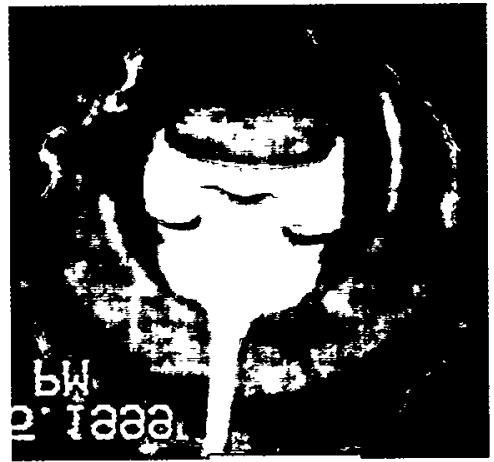

d

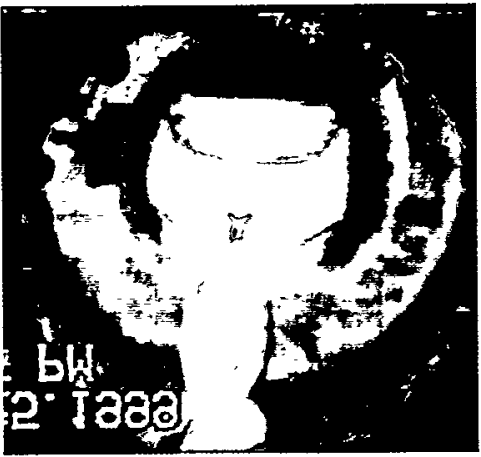

g

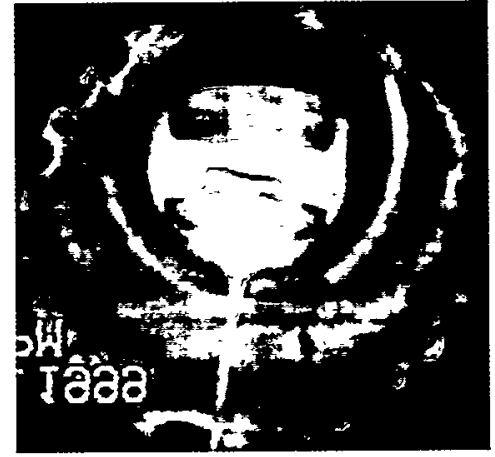

b
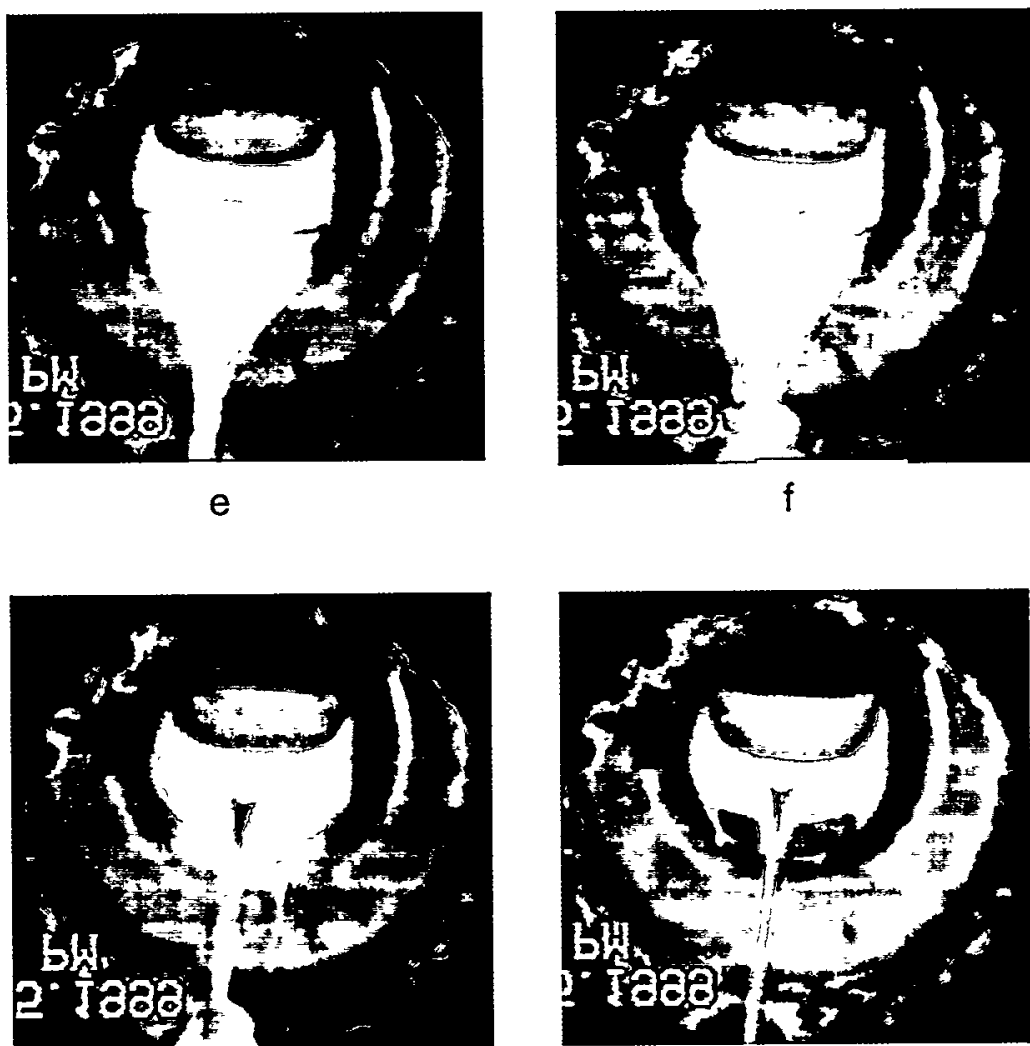

$\mathrm{f}$

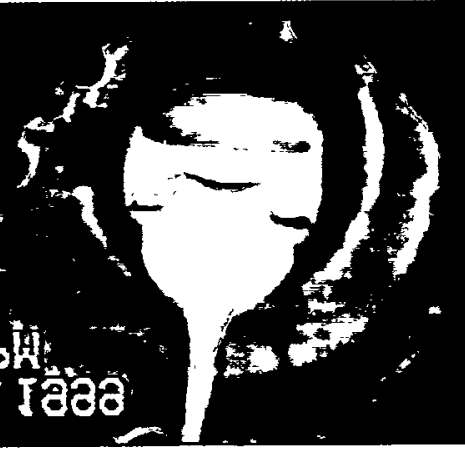

C

h 
Figure 6 Glass Stream Deflections During a 8 lbs Surge at $125 \mathrm{lbs} / \mathrm{hr}$ Flow (23:25_6/25/99)
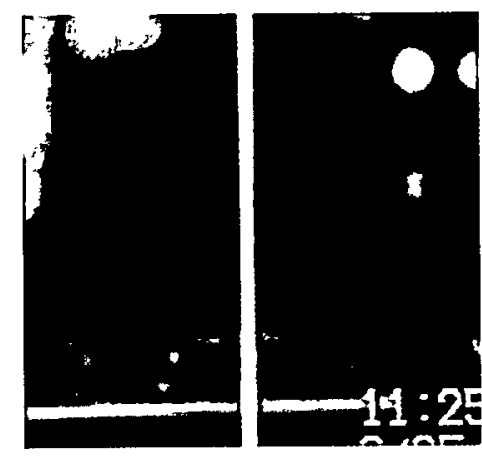

a

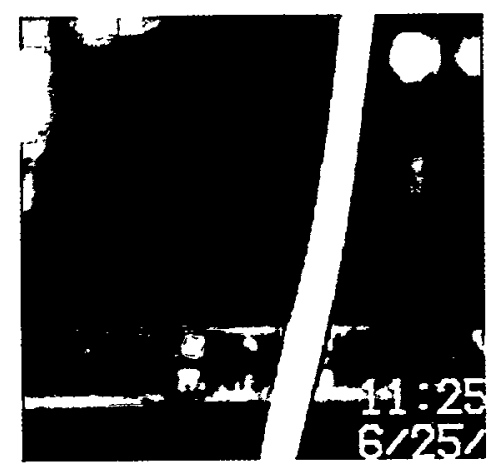

d
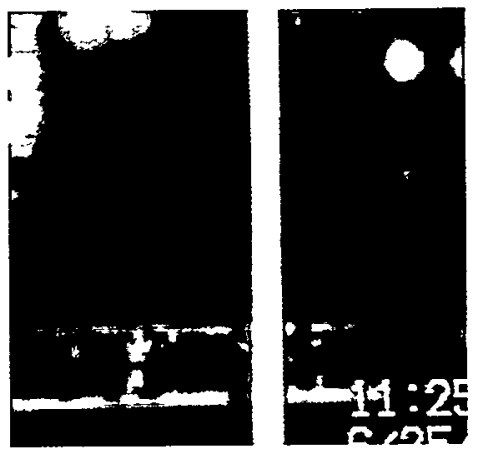

b
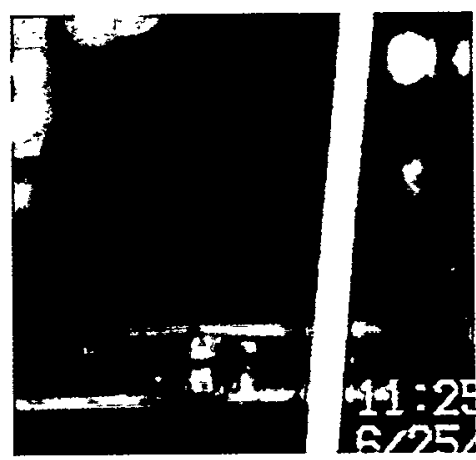

e
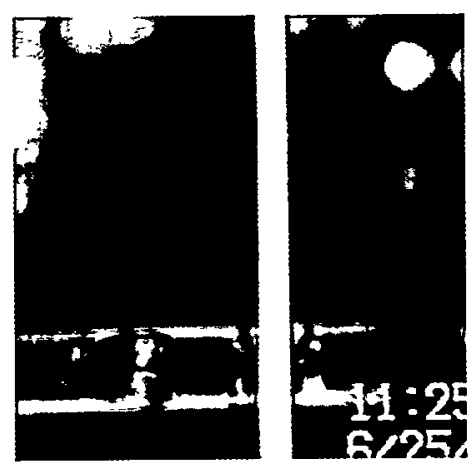

C

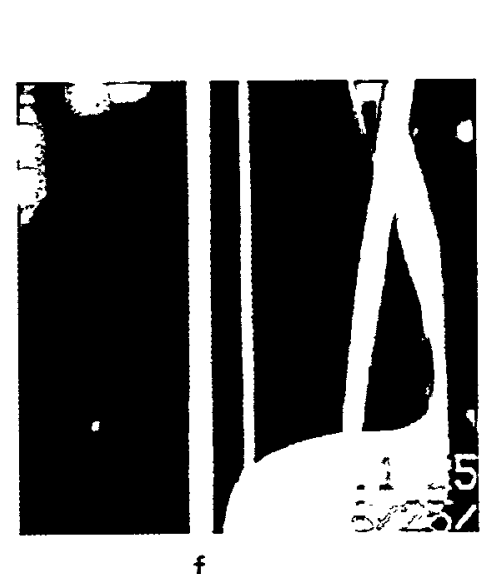

f

Figure 6 provides some video clips from the side camera. Figure 6a shows the position of the stream before the surge. Figure $6 \mathrm{~b}-6 \mathrm{e}$ show the increase in stream width and brightness during the surge and its movement backwards towards the riser (to the right in the figure). Figure $6 \mathrm{f}$ shows the multiple stream resulting from the large wick hitting the insulation. 
Figure 7. Glass Stream Behavior Inside an Insert

At $155 \mathrm{lbs} / \mathrm{hr}$ Flow and $3.9 \mathrm{lbs}$ Surge (21:54-6/25/99)

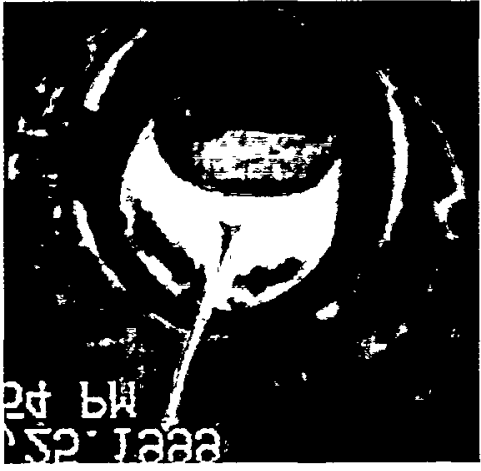

a

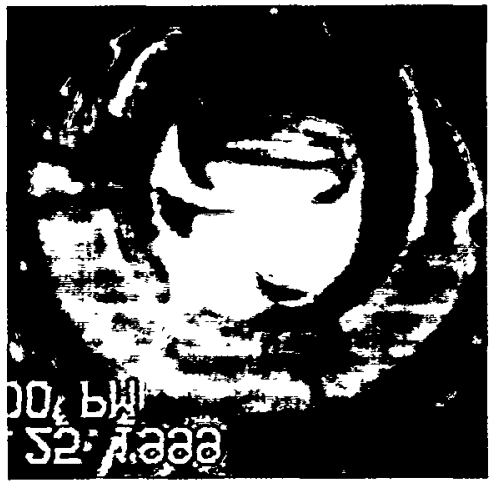

d

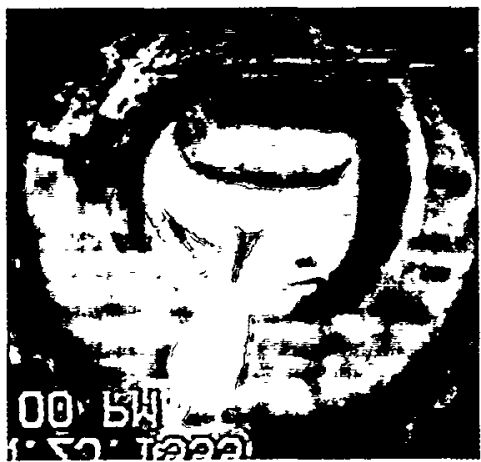

g

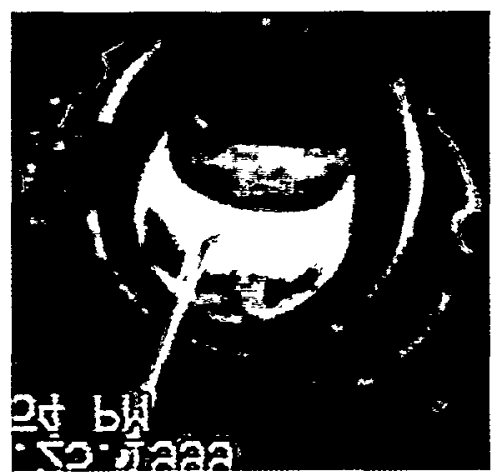

b

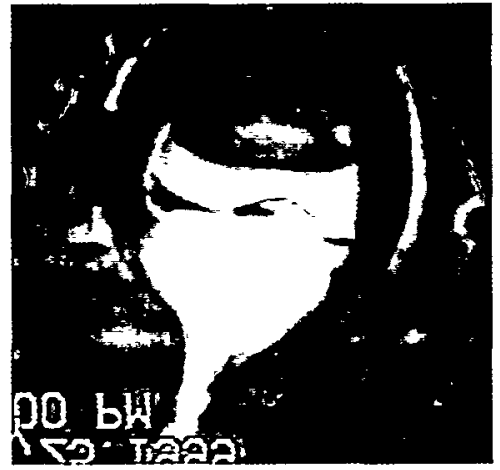

e

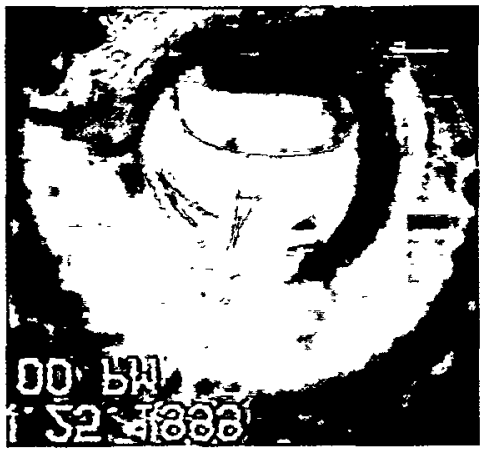

h

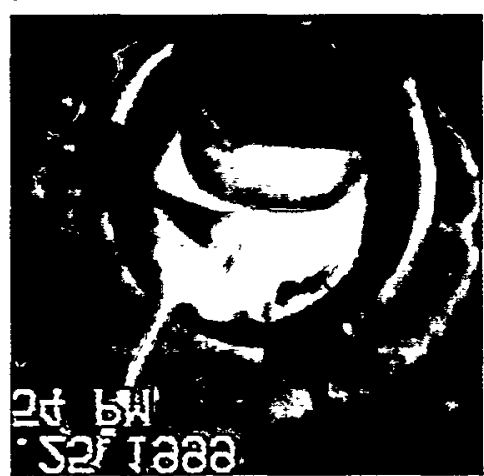

C

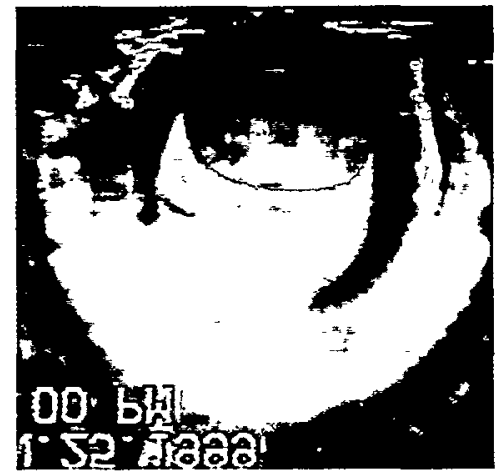

f

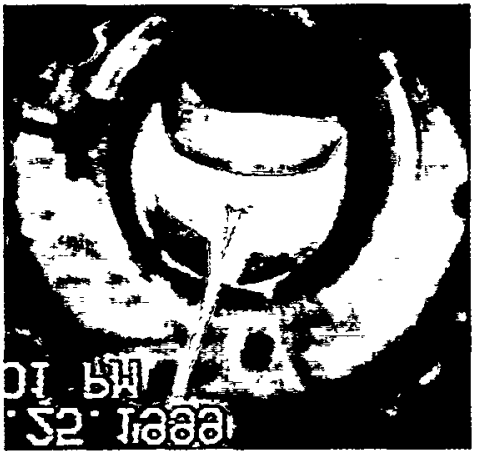

In Figure 7, the steady state flow was $155 \mathrm{lbs} / \mathrm{hr}$ and the glass stream was separating from pour spout knifeedge. Because of the high flow and the small 3.9 pound glass chunk dropped into the pour spout reservoir, the surge front is not evident. However, the increase in flow causes the separating stream to swing to the left, probably because the underside of the separating stream touches the insert wall and by capillary action pulls the stream to the left. The glass then collects on the insert wall and interrupts the flow past the insert. The collecting glass then reaches the insert knife-edge and drops off the insert knife-edge. A steady state flow then 
develops where a flat meniscus develops inside the insert. The glass stream then separated from the insert knife-edge at 30 degrees to the left of the spout centerline.

Figure 8, Glass Stream Deflection Recorded by Side Camera

During a $3.9 \mathrm{lbs}$ Surge and $155 \mathrm{lbs} / \mathrm{hr}$ Flow (21:54-6/25/99)

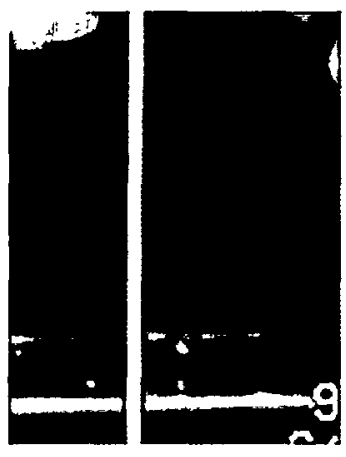

a

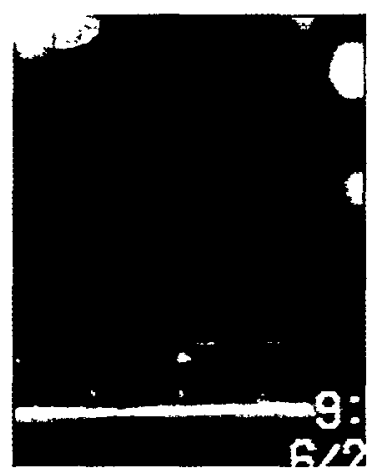

b

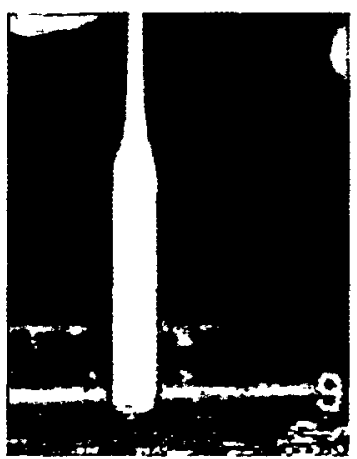

C
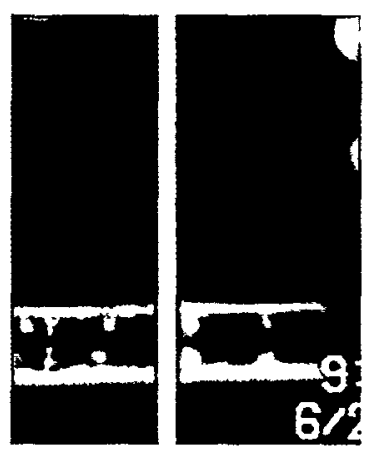

d

Video clips from the side camera are shown in Figures 8. Figure 8a shows the initial position of the glass stream when the stream was separating from the insert knife-edge centerline. Figure $8 \mathrm{~b}$ shows that the glass stream then disappears when it collected inside the insert. Figure 8c shows the front end of the glass stream separating from the insert knife-edge and Figure 8d shows the final position of the glass stream. These images show that there was no large wicks observed during this test. 
Figure 9. Glass Stream Behavior Inside an Insert At $155 \mathrm{lbs} / \mathrm{hr}$ Flow and $8 \mathrm{lbs}$ Surge (22:00-6/25/99)

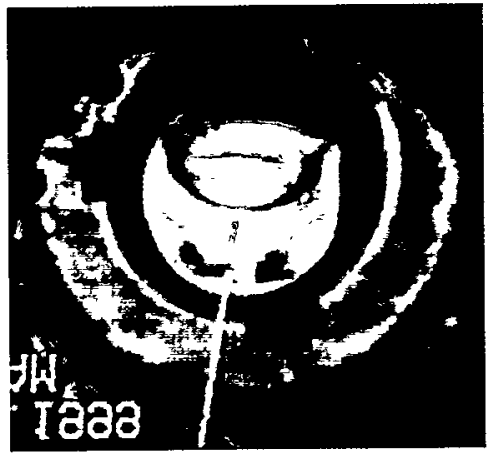

a

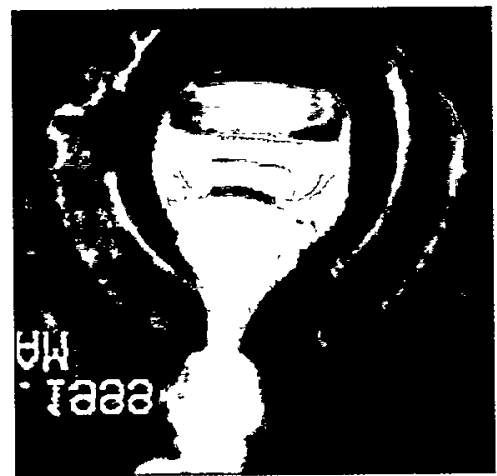

$d$

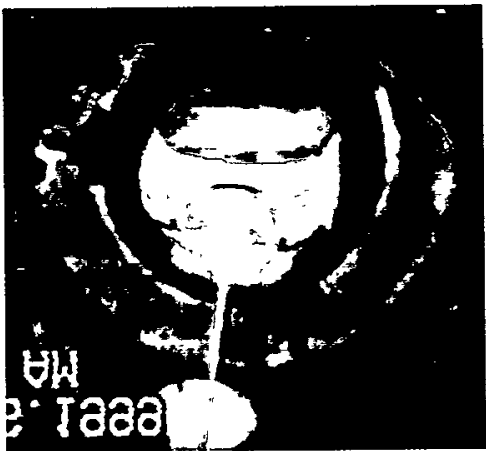

g

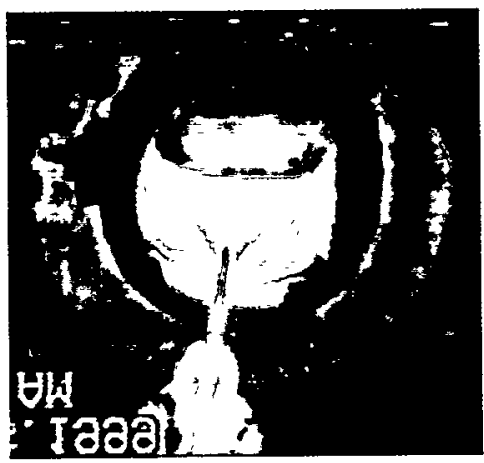

i

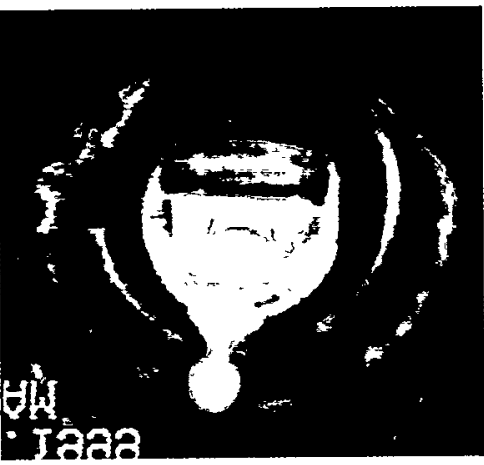

b

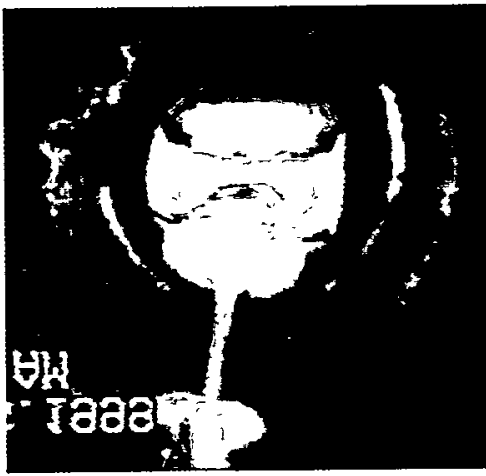

e

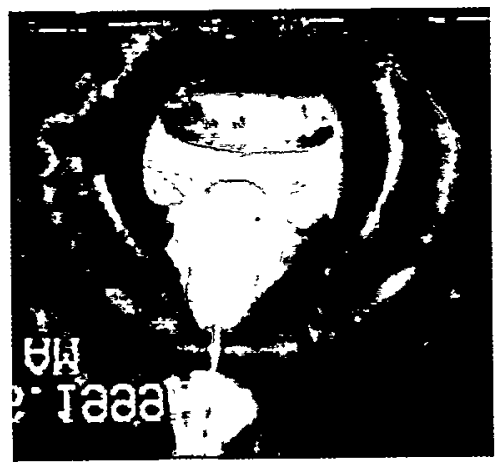

$\mathrm{h}$

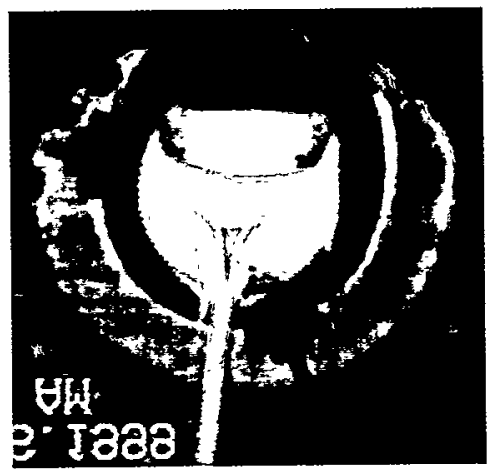

$k$
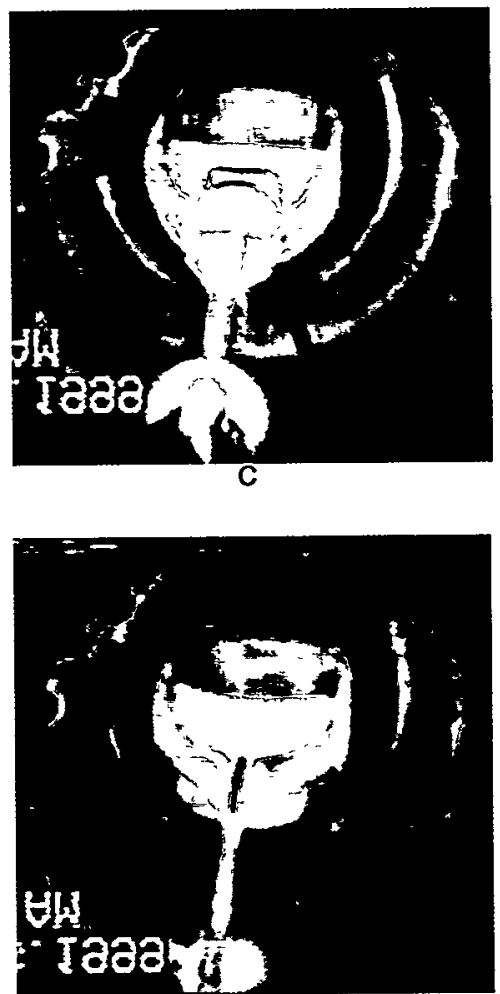

f

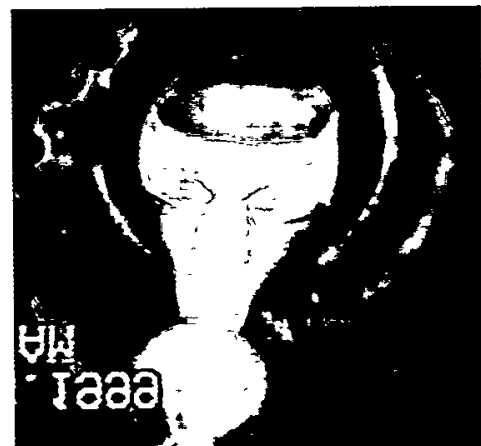

i

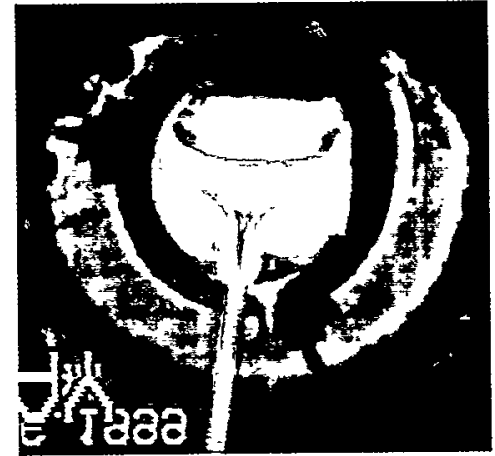

I 
In Figure 9a, the steady state flow rate was $155 \mathrm{lbs} / \mathrm{hr}$ and the glass stream was separating from the insert knife-edge at about 30 degrees to the left of the centerline looking towards the riser. This figure also shows the 8 pound surge front approaching the spout knife-edge. The flow built up inside the insert and there were several large wicks or wavering of the stream (Figures $9 \mathrm{~b}-\mathrm{c}$ ). When the level in the pour spout had decreased (Figure 9d) the stream separated from the pour spout knife-edge centerline. There was a residual stream behind the main stream draining from the insert (Figure 9e) and drips (Figure 9f). In Figure 9g, the flow surge was decreasing and the stream was steady. Then the separating flow swung to the right (Figure $9 \mathrm{~h}$ ) and contacted the insert wall, interrupting flow (Figure 9i). In Figure 9j the flow again built up inside the insert and separated from the insert knife-edge, causing a large wick. In Figure 9k the stream was again steady, separating from the insert knife-edge at about 30 degrees to the right of the centerline. Then the stream moved to the center, (Figure 9l)

Figure 10. Glass Stream Deflection as Recorded by Side Camera

During a $8 \mathrm{lbs}$ Surge at $155 \mathrm{Lbs} / \mathrm{hr}$ Flow (2200_6/25/99)
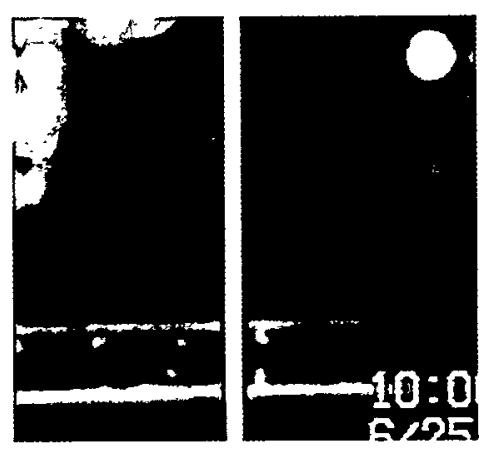

a
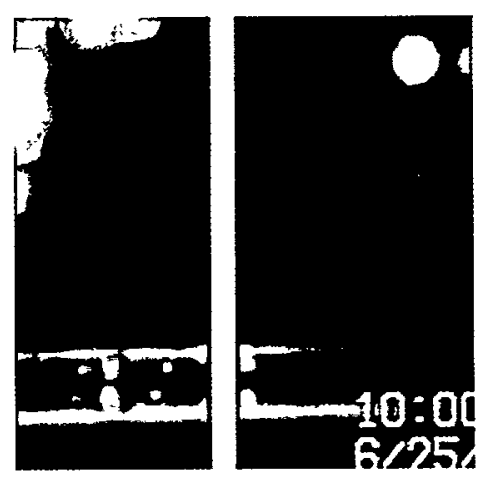

d

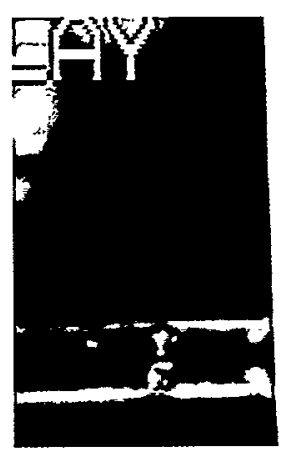

b
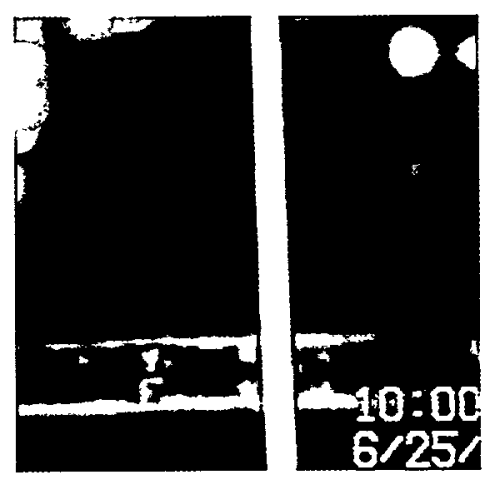

e

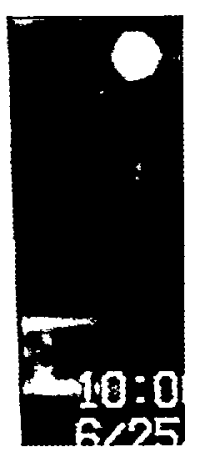

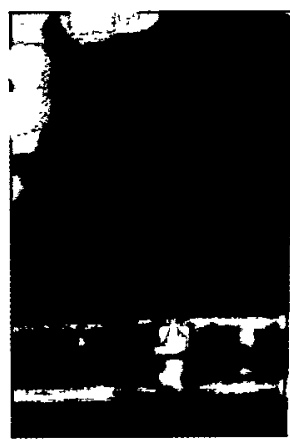

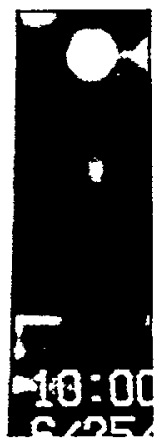

C
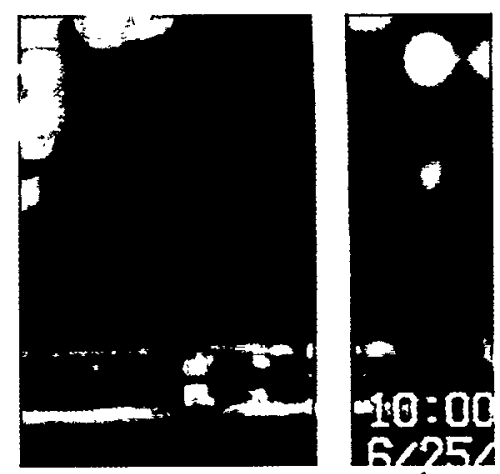

f

Some clips from video recordings with the side camera are shown in Figures 10a-10f. Figure 10a shows the initial position of the stream while Figures $10 \mathrm{~b}-10 \mathrm{f}$ show the movement of the stream back and forth from the center to the right. Maximum deflections of up to one inch are evident from the ruler. 
Figure 11. Glass Stream Behavior Inside an Insert At $42.2 \mathrm{Lb} / \mathrm{hr}$ Flow and 4 Lbs Surge (0009_6/26/99)

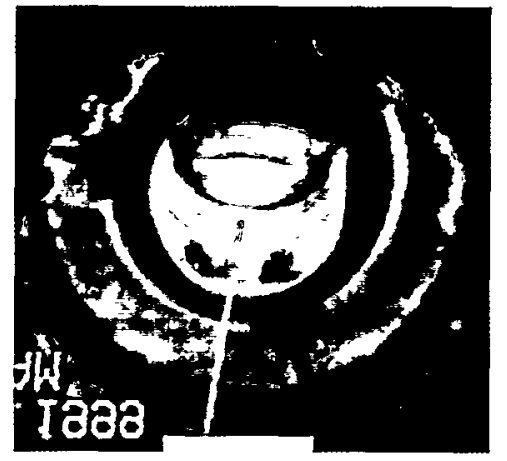

a

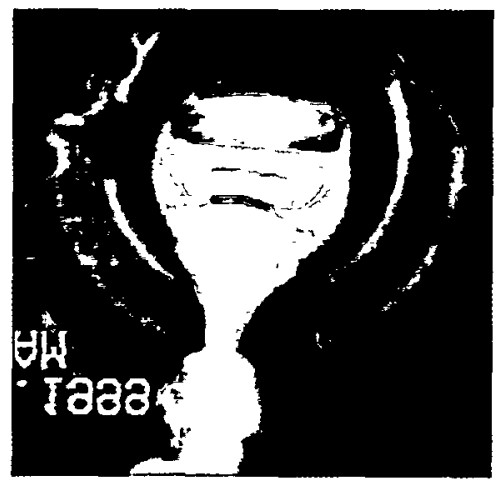

d

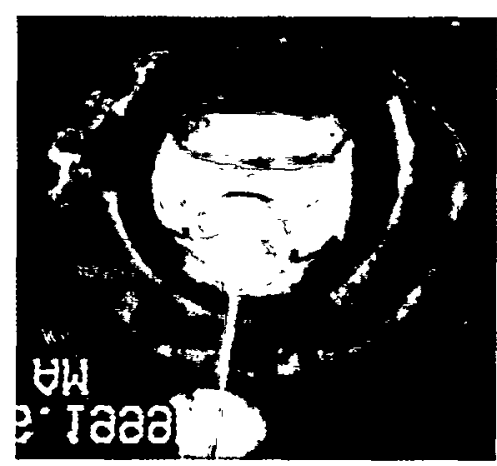

g

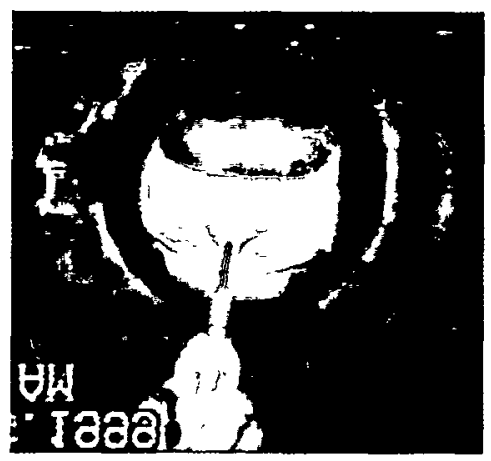

j

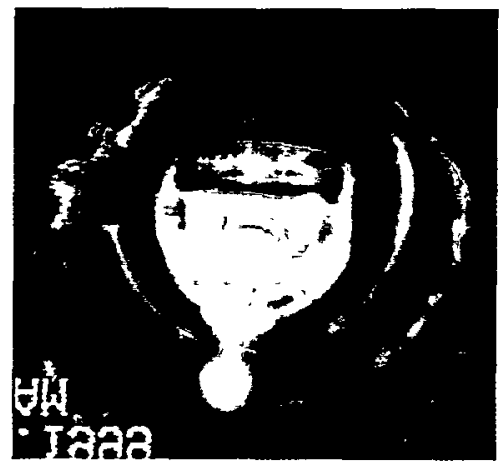

b

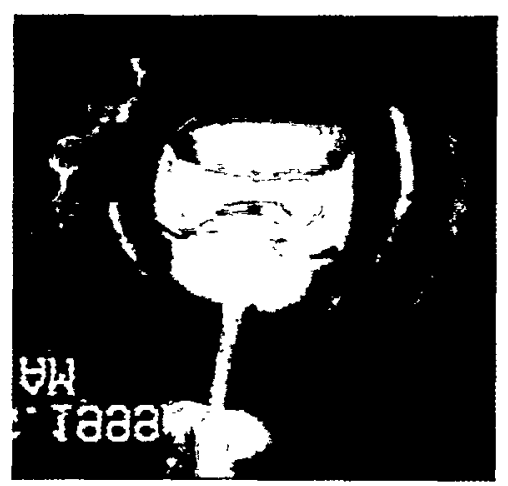

e

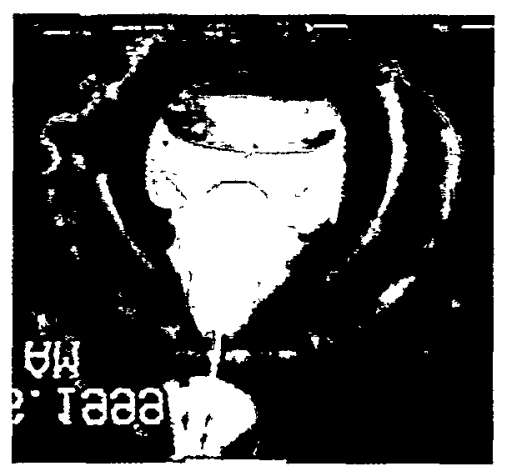

h

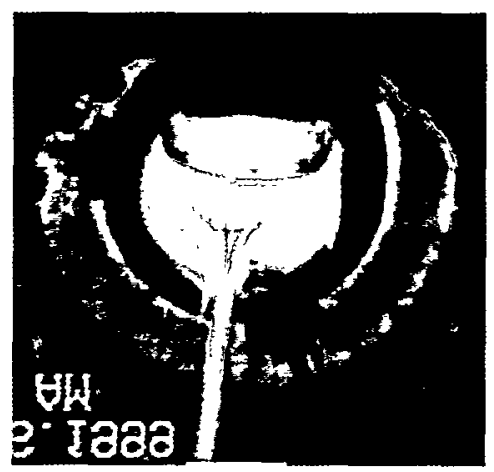

k

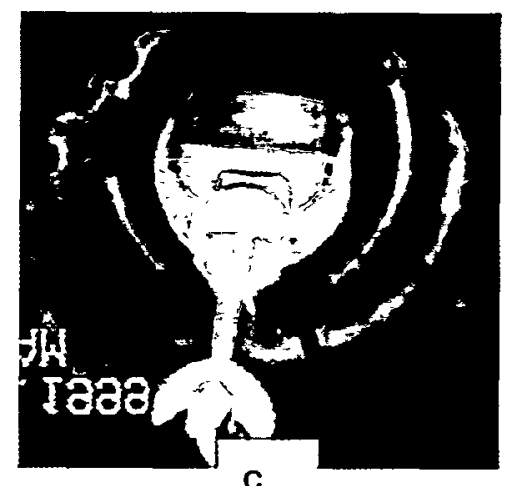

c

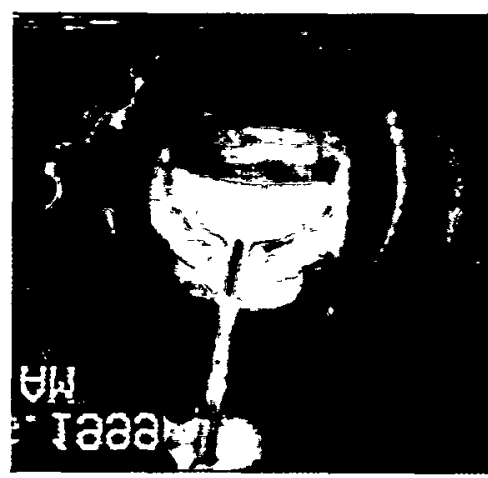

f

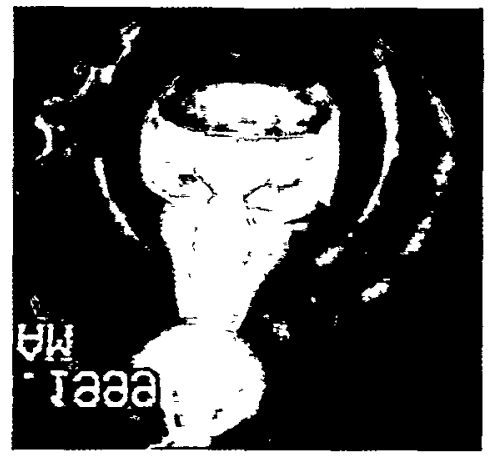

i

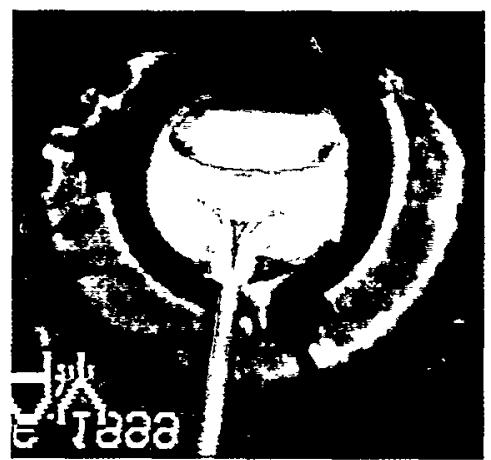


For the surge test shown in Figure 11, the steady state flow rate was $42.2 \mathrm{lbs} / \mathrm{hr}$ where the previous flow rate was higher. Figure 11 a shows the initial flow separating from the insert knife-edge. The surge front due to a 4 pound drop test can be seen inside the pour spout. In Figure 11b, the stream deflects inside the insert and hits the insert wall. Glass then collects, and interrupts the flow out of the insert. Spreading of the glass downward is aided by gravity while capillary forces are limited in the lateral direction. This causes rounding of the stream and an increase in height, which might also be aided by surface tension. The leading edge of the surge front reaches the insert knife-edge and deflects backwards. Figure 11c shows the deflecting stream hitting the cold collected glass on the insulation opening. In Figure 11d, the increase in level in the pour spout results in continuous wicking. In Figure 11e, the pour spout level has decreased to a medium level and a meniscus forms in the glass stream inside the insert. The glass then separates from the pour spout knife-edge (Figure 11f) and a repeated wicking occurs with a medium frequency, repeating the alternate glass separation from the pour spout and insert knife-edges. Figures $11 \mathrm{~g}-11 \mathrm{i}$, the level in the pour spout has significantly decreased but surging still occurs inside the insert although with a longer period. In Figure 11i, one last large surge occurs. The glass then finally separates from the pour spout knife-edge (Figure $11 \mathrm{k}$ ). From Figures $11 \mathrm{k}$ and $11 \mathrm{l}$, one can see a second stream swing from side to side behind the main stream. This is similar to what was observed in the DWPF Pour Spout.

Figure 12 Glass Stream Deflection as Recorded by the Side Camera

During a $4 \mathrm{lbs}$ Surge at $41.5 \mathrm{lbs} / \mathrm{hr}$ Flow (00:09-6/26/99)

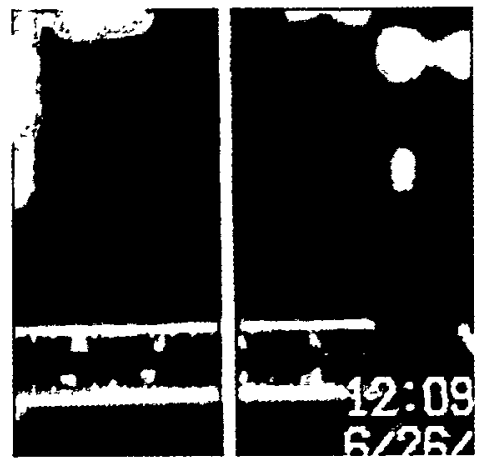

a

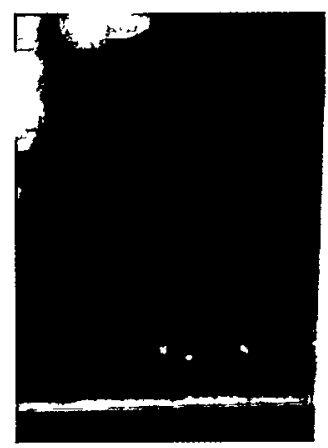

d

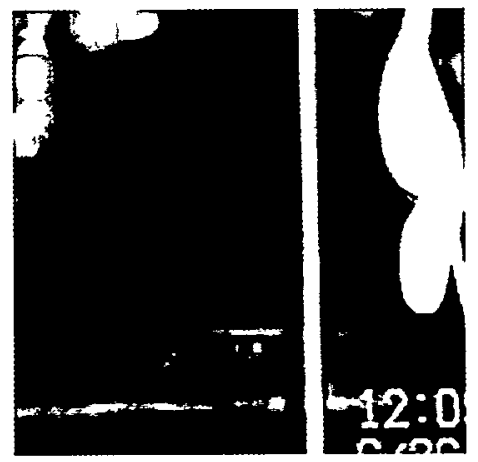

b

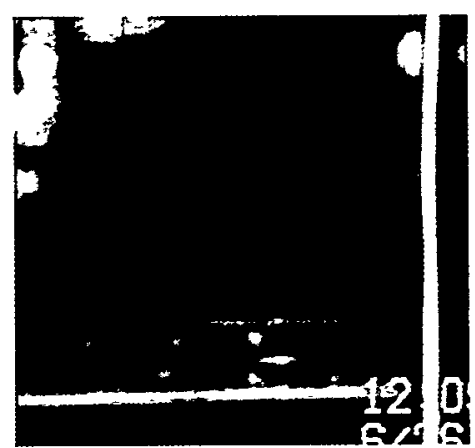

e
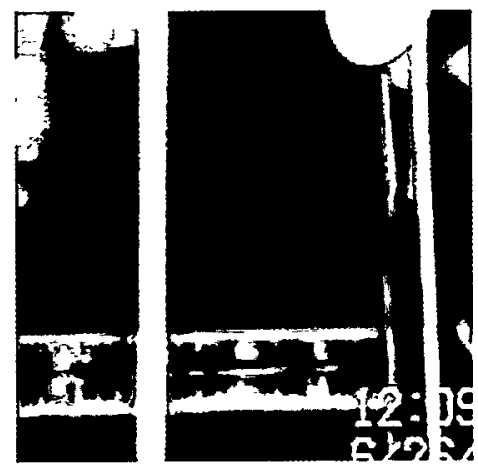

C
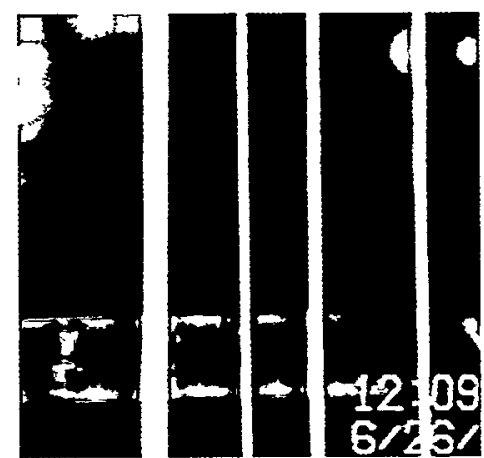

f 
WSRC-TR-99-00232, Rev. 0

Figures 12a-12f show some video clips of the glass stream as it swings backwards and forwards repeatedly during this test. The last figure shows multiple streams resulting from the last large wick.

The general pattern of wetting behavior in the spout is compatible with the surface tension measurements of molten glass on oxidized Inconel $690^{\mathrm{TM}}$. Under steady state conditions, the glass forms a thin, concave crescent-shaped ribbon approximately half way around the spout. At the knife-edge the glass collects with surface tension pulling the stream into a roughly circular cross section. The wetting is not instantaneous, and during surging the main flow of the glass can form a thick convex spine along the centerline of the wetted area. At very high flows the convex section can bulge and separate from the knife-edge, resulting in very erratic flow.

The junction between the spout and the insert is critical for control of surging conditions. If there is mismatch, the stream can separate from the insert and drop from the knife-edge instead of the insert. Later the stream may reattach itself to the insert and accumulate material, thereby, resulting in an erratic slug of glass.

\section{Pour Spout Geometry Effects}

- Eroded Knife-edge

This testing is being conducted by Florida International University and will be reported separately.

\section{Replacement Spout}

- Design study of replaceable heater

The thermal data from the DWPF Pour Spout Test Stand is being evaluated to determine what changes are practical. An auxiliary heater near the bottom of the spout that would level out temperature gradients in the area of the insert would be advantageous.

- Design study of replaceable riser/pour spout

Based upon discussions with DWPF, it is unlikely that major changes to the spout are practical. Minor changes to the shape of the serpentine heater may improve thermal gradients at the bottom of the spout.

- Design study of replaceable knife-edges

An alternative knife-edge design should be developed that is specific for the use of inserts. This would feature positive alignment between the spout and the insert, and minimum disruption of the glass flow at the junction. The design would also need to accommodate geometry changes resulting from spout oxidation and corrosion.

- Engineering test of replaceable knife-edges

Tests of alternative designs can be conducted in FY 00. This could include a short insert, which effectively repairs knife-edge corrosion provided that gauging of the worn spout can be conducted. Photographic methods hold the best promise for this since they are non-intrusive. Simple imaging methods have been effective on the DWPF Pour Spout Test Stand. 


\section{Pour Spout Inserts}

- Insert nominal configuration

Testing was conducted under a range of flow conditions and temperatures. Results are reported above.

- Insert improved configuration

Testing will be conducted in FY 00 .

- Effect of insert/knife-edge gap

Testing will be performed in FY00.

- Effect of variable gap (cocked insert)

Testing has been done with the insert in a "cocked" configuration. The flow patterns were normal but noticeable rippling of the stream occurred at the junction where the knife-edge and insert met. A small amount of glass flowed down the back edge. The viscosity of the glass that adhered to the lower portion of the spout was typical of DWPF indicating the temperature of this region is similar to DWPF conditions.

\section{Alternative Spout Designs}

- Plug/Seat wetted tube knife-edge - horizontal

The drain on the primary tank was tested and lacked sufficient heat. Gaps in the insulation were plugged to reduce the "chimney" effect of cold air flowing past the spout and cooling it. However, the heater was still insufficient to heat the valve assembly. A propane burner is used to provide sufficient heat to initiate pouring. The plunger / valve seat system used in this arrangement is good at controlling glass flow when sufficient heat is available.

- Plug/Seat wetted tube knife-edge - vertical

Superheater drain. The cylindrical heater assembly on the drain burned out during initial operations and needs design changes to be more remoteable. The original heaters were replaced with larger diameter, longer, and more powerful heaters. Pour rates were achieved between 20-300 lbs/hr.

- All Inconel $690^{\mathrm{TM}}$ overflow spout

The Inconel $690^{\mathrm{TM}}$ overflow connecting the Primary Tank to the Superheater operated satisfactory. The spout is restrictive to flow and allowed an excessive inventory of glass to build up in the Primary Tanks. This resulted in glass leakage at the section of the Superheater which mates to the Primary Tank. This condition would be improved by better instrumentation of the Primary Tank and Superheater glass levels, a less restrictive overflow spout, and increased freeboard in the Superheater.

\section{Wear \& Corrosion Tests}

- Comparison of initial to final dimensions of tank, agitator, spout and similar components 
Initial dimensions of the Primary Tank wall thickness, agitator dimensions, and dimensions of the plugs in valves for the Superheater have been recorded for comparison to after test dimensions. Some corrosion has been noted at the junction of the agitator and the drive shaft. This corrosion is attributed to molten salt attack of the copper base alloy of the drive shaft.

- Alternative material coupon tests

SRTC will evaluate potential alternative alloys before making coupons.

\section{Noble Metal Behavior and Effects}

Noble metal effects in other melter systems have been discussed at a technical exchange held in Augusta, GA May 4-5, 1999. The results of the workshop are being reported separately by PNNL.

- Sedimentation in Stirred melter

- Agitator suspension of insoluble particles

\section{CONCLUSIONS}

End effects at the bottom of the Riser and radiative heat loss from the end of the spout cause the lower portion of the Riser to be cold enough that glass sticks to it and accumulates. Depending upon specific circumstances the cold glass may drip like cold tar or accumulate on the Riser. Accumulated cold glass tends to devitrify (changing from glass to a combination of glass and crystals). Once devitrified, the glass is more difficult to remove mechanically and generally stops flowing. In DWPF, this led to reboring of the pour spout to produce knife-edges in the hotter regions of the temperature gradient, thereby improving the glass separation from the metal tube.

The current combination of a large diameter Bellows Shield and centering of the Bellows Shield on the Normal Disengagement Point (with clearances to allow the pour stream to wander around the bore of the Pour Spout) requires a large diameter transition piece which aggravates thermal gradients in the Pour Spout. If the location of the Disengagement Point can be controlled such that it is a Unique Disengagement Point, then this would permit reduction of the bore diameter in the thermal insulation between the bottom of the heated Pour Spout Section and the Bellows Section. Radiative heat loss could probably then be reduced by $50 \%$ or more. Long term programs should include thermal modeling, fluid modeling, and physical testing to improve this portion of the design.

One of the major current findings of the team is a better understanding of the surface effects of the Pour Spout and the glass. Normally, these effects are rarely considered since they are difficult to monitor and control at molten glass temperatures. Normally stronger forces overwhelm their effect. However, in the pour spout the glass flows down a vertical tube. Therefore small forces such as surface tension or irregularities in the shape or finish of the surface, can spread the glass stream out or cause it to shift direction. We are indebted to the work of J. Sproull and C. Cicero-Herman who worked with the New York State College of Ceramics to better define surface tension and viscosity effects. They found that the glass wets both unoxidized and preoxidized Inconel $690^{\mathrm{TM}}$ at very low contact angles (typically 4 to $40^{\circ}$ ). This effect has been confirmed in the DWPF pour spout with radioactive glass which appears to be totally wetted in the upper section. Also in videos this effect has been seen to form ribbons along the knife-edge rather than pencil shaped streams. The ribbons may result in drips from different portions of the ribbon, or even multiple streams or oscillating streams. The ribbon pouring has been simulated on a physical model and appears to have several forms of instabilities which could distort the shape and location of the glass stream. Molten salts have also been found in the melter pour spout and their effect on the wetting characteristics has not been determined. Molten salts are possible causes 
of corrosion in the Pour Spout, leading to changes in geometry which cause pouring difficulties. The combination of surface tension effects and crystallization in the upper section has been proven to result in a stable glass film up to a 1/8 of an inch thick all the way around the spout. These effects reinforce a new design requirement of a Unique Disengagement Point to control the separation of the glass from the Pour Spout.

A Unique Disengagement Point should have at least four design elements. First, the design should be insensitive to surface effects, leading the glass to flow to a single point and disengage from that point whether the spout is clean or fouled, oxidized or unoxidized, eroded or freshly machined, and not sensitive to fluctuation in surface tension and wetting angles. Thus, the design needs the second criteria, a force to restore the flow down the pour spout to the vertical line closes to the melt chamber. This might be accomplished by inclining the bore slightly to produce a trough with gravity and the curvature of the bore producing the restoring force. The third criteria is to have the final disengagement point as the lowest point in all directions, with a slope from other surrounding areas to be determined by future tests. This feature tends to gather back any wandering portions of the stream traveling down the tube and therefore, stabilizes the cross section shape and size of the stream. The fourth feature is to have the cross section of the metal near the disengagement point as symmetric as possible. This feature is to introduce symmetry near the Disengagement Point to minimize lateral wandering of the stream caused by velocity, viscosity, and momentum gradients as the glass transitions from being guided by the metal to a free falling condition. Conceptual designs are shown in Figure 13.

\section{POST TEST REPORTING}

Upon completion of the Stirred melter testing, results will be documented in a Tanks Focus Area

Report. Additionally, an annual report on the Clemson/INEEL Melter Work will be issued by September 30, 1999.

\section{ACKNOWLEDGMENTS}

The authors of this paper would like to express their appreciation to the following persons for their contributions to this test program:

D. Erich, J. Harden, T. Pruett of Clemson Environmental Testing Laboratory; Marvin Trimm; Vernon Bush, Victor Buch; George Adondakis; Nick Odom; Tim Jones; Don Miller; Cary Miller; Paul Burket.

\section{REFERENCES}

1. “Kepner-Tregoe Final Report”, WSRC-OPS-DTP-970070, J. Morin, April 29,1997.

2. Subtask C, "Second Generation DWPF Melter", TTP\# SR1-6-WT-31, January 15, 1999.

3. “Task Technical and QA Plan: Melter Performance Improvements", WSRC-RP-99-00326, D. F. Bickford and J. C. George, June, 1999.

4. "Experimental Test Plan for Improve Performance of HLW Melter Test (U), SRT-GFM-99-0017 Rev. 0, D. R. Bickford and J. C, George, June 16, 1999.

5. “DWPF Melter-1 Pour Spout Insert (U)”, WSRC-OPS-DTO-9X00XX, D.C. Iverson, January 28, 1996.

6. "Evaluation of Materials and Surface Treatments for the DWPF Melter Pour Spout Bellows Protective Liner (U)"WSRC-TR-97-0113 Revision 0, K.J. Imrich, D.F. Bickford, G.G. Wicks. 
WSRC-TR-99-00232, Rev. 0

7. "Metallurgical Evaluation of an Inconel 690 Insert from a Radioactive Waste Glass Melter Pour Spout", K. J. Imrich and D. C. Iverson. 

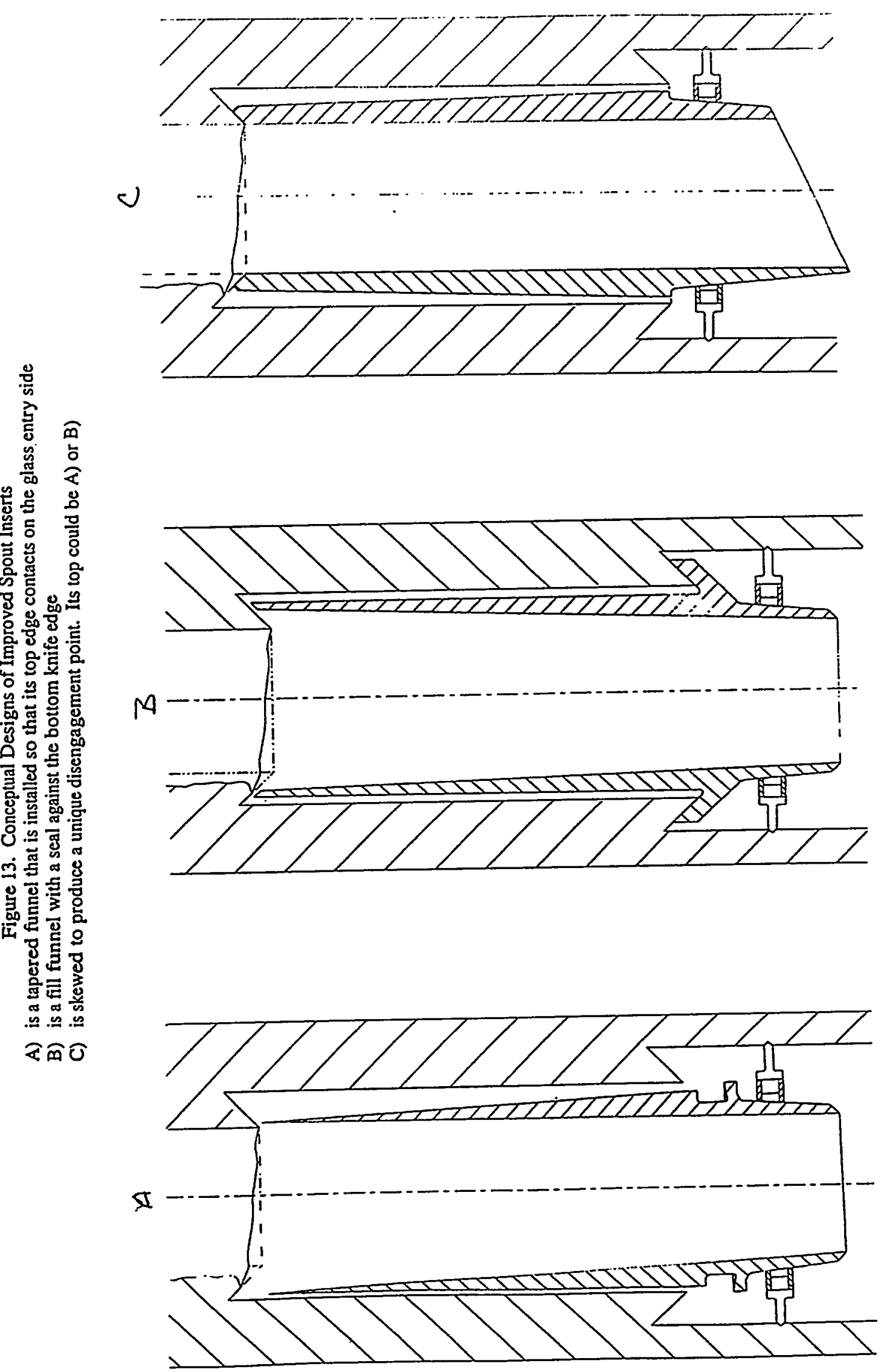